\title{
Targeting NF-kB pathway for treating ulcerative colitis: comprehensive regulatory characteristics of Chinese medicines
}

\author{
Peng-De Lu ${ }^{\top}$ and Yong-Hua Zhao ${ }^{2^{*}}$ (I)
}

\begin{abstract}
Nuclear factor-kappa B (NF-KB) is a kind of multi-functional nuclear transcription factor involved in regulating gene transcription to influence pathological evolution of inflammatory and immune diseases. Numerous literature evidence that NF-kB pathway plays an essential role in pathogenic development of ulcerative colitis (UC). UC is a chronic non-specific inflammatory bowel disease, and until now, therapeutic agents for UC including aminosalicylates, corticosteroids and immune inhibitors still cannot exert satisfied effects on patients. In recent years, Chinese medicines suggest the advantages of alleviating symptoms and signs, decreasing side-effects and recurrence, whose one of mechanisms is related to regulation of NF-KB pathway. In this review, we categorize Chinese medicines according to their traditional therapeutic functions, and summarize the characteristics of Chinese medicines targeting NF-KB pathway in UC treatment. It indicates that 85 kinds of Chinese medicines' compounds and formulae can directly act on NF-kBp65; while 58 Chinese medicines' ingredients and formulae indirectly suppress NF-kBp65 by regulation of its upstream or other related pathways. Moreover, by the analysis of Chinese medicines' category based on their traditional functions, we conclude the category of dampness-drying and detoxificating medicine targeting NF-KB pathway accounts for primary status for amelioration of UC. Simultaneously, this review also contributes to the choices of Chinese medicine category and provides curative potential of Chinese medicines for clinical UC treatment.
\end{abstract}

Keywords: Ulcerative colitis, Chinese medicines, NF-kB, Characteristics

\section{Background}

In recent years, the incidence and prevalence of global ulcerative colitis (UC) have shown a rapidly increasing trend. It suggests that the highest prevalence rate of UC (505/100,000 in Norway) exists in western Europe, and the prevalence rate of UC in Korea increases from $0.34 / 100,000$ in $1986-1990$ to $3.08 / 100,000$ in $2001-2005$ $[1,2]$. Statistical data show that the prevalence rates of Heilongjiang, Xian, Guangzhou, Zhongshan, Hong Kong

\footnotetext{
*Correspondence: yonghuazhao@um.edu.mo

${ }^{2}$ State Key Laboratory of Quality Research in Chinese Medicine, Institute of Chinese Medical Sciences, University of Macau, Taipa 999078, Macao, Special Administrative Region of China

Full list of author information is available at the end of the article
}

and Taiwan are 1.77/100,000, 0.42/100,000, 3.44/100,000, $3.14 / 100,000,3.06 / 100,000$ and $4.59 / 100,000$, respectively [3-5]. Moreover, compared with UC in western countries, the disease in China is found to have some differences in clinical characteristics [6].

Typical symptoms of UC include diarrhea, mucus pus, bloody stools and abdominal pain, and its time of onset is more than 4 to 6 weeks, simultaneously, extraintestinal manifestations involve skin mucosa, joints, eyes, lungs and nervous system [7-15]. Additionally, diarrhea, which does not exceed 6 weeks of disease process, needs to be distinguished from infectious enteritis [16]. Presently, western medicine generally thinks that there are several pathological factors related to UC, including

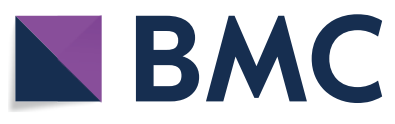

(c) The Author(s) 2020. This article is licensed under a Creative Commons Attribution 4.0 International License, which permits use, sharing, adaptation, distribution and reproduction in any medium or format, as long as you give appropriate credit to the original author(s) and the source, provide a link to the Creative Commons licence, and indicate if changes were made. The images or other third party material in this article are included in the article's Creative Commons licence, unless indicated otherwise in a credit line to the material. If material is not included in the article's Creative Commons licence and your intended use is not permitted by statutory regulation or exceeds the permitted use, you will need to obtain permission directly from the copyright holder. To view a copy of this licence, visit http://creativeco mmons.org/licenses/by/4.0/. The Creative Commons Public Domain Dedication waiver (http://creativecommons.org/publicdomain/ zero/1.0/) applies to the data made available in this article, unless otherwise stated in a credit line to the data. 
genetic factor, infectious factor, intestinal microbiota imbalance, immune response, dietary factor and so on. Study evidences that less than $20 \%$ of susceptibility genes are associated with UC and 28 functional chromosomal loci have been reported [17]. A 10-year study on cytomegalovirus colitis shows that it has been a poor prognostic indicator among patients with UC onset [18]. Probiotics have been demonstrated to be able to protect intestinal mucosal barrier and reduce intestinal inflammation, and evidences indicate that a protective role of bifidobacteria in experimental induced colitis is related to regulation of an innate immune response of the host, and immune homeostasis contributes to the reduction of inflammatory bowel disease (IBD) onset [19, 20]. With the improvement of people's living standards, the dietary structure begins to change. The intakes of meat and egg-milk products gradually increase and dietary fiber-based foods decreases. This high-protein and low-vegetable fiber diet has become one of the risk factors for enhancing prevalence of UC [21]. Moreover, excessive intakes of high-calorie and heterologous proteins may stimulate the body's immune response, leading to aggravation or recurrence of $\mathrm{UC}$, while diet strategy of reducing unsaturated fatty acids in food is effective on UC treatment [22].

Current therapeutic drugs for UC include 5-aminosalicylic acid (5-ASA), glucocorticoids, immunomodulators, biological agents and traditional Chinese medicines. The evidence-based consensus released by European Cron's and Colitis Organisation (ECCO) recommends 5-ASA as the primary drug for the treatment of mild to moderate UC and maintaining drug during remission [23]. An analysis on mild to moderate $\mathrm{UC}$ and remission of UC shows that $50.5 \%$ patients with local treatment and $41.3 \%$ patients with oral treatment achieve clinical amelioration, but the incidence of adverse reactions in local and oral treatments was $22 / 105$ (21.0\%) and 36/109 (33.0\%), respectively [24]. Glucocorticoids are prone to hormone dependent and resistant. In the treatment using budesonide foam enema for mild to moderate UC, the rate of side effects was $45.9 \%$ [25]. Therefore, glucocorticoids are not suitable for long-term application for maintaining treatment. Immunosuppressive agents have more significant adverse reactions such as nausea, vomiting, abdominal pain, severe diarrhea, myelosuppression, hepatotoxicity and pancreatitis, and in the treatment of biological agents, a large number of patients do not get mucosal healing and the mucosal healing also does not mean that the symptoms disappear [26, 27]. Although the above drugs have achieved a certain extent effects on clinical remission of UC and promoting mucosal healing, it still cannot meet the requirements of $\mathrm{UC}$ treatment.
Clinically, Chinese medicines not only obviously improve symptoms and accelerate ulcer healing, but also alleviate adverse reactions of western medicine and enhance patients' quality of life. Therefore, Chinese medicines have become a hotspot in UC treatment in recent years [28-32].

Data show that $20.1 \%$ of UC patients in China accept the treatment of Chinese herbs, and $59.1 \%$ are administered with combined Chinese with western medicines [33]. Moreover, Chinese medicines are reported to be satisfied efficacious in the treatment for mild to moderate UC [34]. It shows that combination treatment of Chinese medicine formula and mesalazine notably improves the intestinal symptoms, mucosal condition, and extraintestinal characterizations compared to mesalazine alone in UC patients after 8 weeks [35]. Another study indicates that the therapeutic effect of curcumin combined with mesalamine is superior to that of mesalamine in patients with mild-to-moderate UC, and no apparent side effects emerge [36].

Although precise mechanisms are still not clear at present, numerous literature suggest that NF- $\mathrm{KB}$ pathway plays a central role in regulating the release of cytokines in patients with UC and participates in the inflammation and immune response in the intestinal tract of UC [37-39]. The imbalance between excessive secretion of pro-inflammatory cytokines and relative insufficient secretion of anti-inflammatory cytokines is linked to the development of non-specific inflammatory responses in the intestine [40]. It indicates that NF- $\mathrm{kBp} 65$ highly expresses in intestinal mucosal epithelium, crypt epithelial cells and lamina propria monocytes of patients with UC, and the expression of NF- $\mathrm{kB}$ in the nucleus is significantly higher than that in cytoplasm [41]. NF-kappaB p65 antisense oligonucleotides blocks NF- $\mathrm{B}$ pathway and down-regulates NF- $\mathrm{kB}$-dependent IL-1beta and IL-8 mRNA expressions, which attenuates the productions of pro-inflammatory cytokines in lamina propria mononuclear cells from patients with UC [42]. In this review, based on the therapeutic superiorities of Chinese medicines and the important role of NF- $\mathrm{KB}$ pathway in UC pathogenesis, we summarize Chinese medicines and their active compounds as well as Chinese medicine formulae targeting NF- $\mathrm{kB}$ signaling pathway, and further analyze the characteristics and advantages of Chinese medicines during the process of $\mathrm{UC}$ treatment.

\section{Traditional Chinese medicine's pathogenesis of UC and therapeutic strategy}

According to the etiology and pathogenesis theory of traditional Chinese medicine, the pathogens of dampness-heat and dampness-cold account for predominant status in the onset of UC. Subsequently, 
qi stagnation and blood stasis present in intestine, which exacerbates the symptoms of UC, e.g., abdominal pain, diarrhea, mucus pus and bloody stools. Additionally, emotion disorder and unhealthy diet lead to the disharmonization of liver and spleen functions, triggering cold and heat in complexity resulting in the change of stomach-intestine environment. Consequently, the pathological development injures spleen qi and kidney yang, causing the deficiency of spleen and kidney functions. Patients with chronic UC are prone to attract complications by exopathogenic factors, because it always exists deficiency in spleen qi and kidney yang. Therefore, UC is commonly divided into "syndrome of dampness-heat", "syndrome of deficiency-cold of spleen and stomach", "syndrome of deficiency of spleen and kidney Yang" and "syndrome of cold and heat in complexity", "syndrome of qi stagnation and blood stasis" and so on [43]. In the treatment of UC, clearing heat, drying dampness, detoxifying, and activating qi and blood, harmonization of cold and warm, warming yang, tonifying qi are regular therapeutic methods.

\section{Chinese medicines and their active compounds targeting NF-KB pathway}

At present, regulation of NF- $\mathrm{kB}$ pathway has become a key strategy in the treatment of UC. According to traditional Chinese medicinal functions, we categorize Chinese medicines and their active compounds targeting NF-kB pathway into seven types.

\section{Heat-clearing and dampness-drying medicine}

Casticin, a compound extracted from Vitex Fructus, showing anti-inflammatory and antitumor effects. Research suggests that casticin $(10 \mathrm{mmol} / \mathrm{L})$ treatment alleviates body weight loss, colon length shortening and pathological damage in the colon of dextran sulfate sodium (DSS)-treated mice, as well as inhibits the productions of pro-inflammatory chemocytokines through down-regulating $\mathrm{AKT} / \mathrm{NF}-\mathrm{kB}$ pathway in macrophages [44].

Baicalin, wogonin and wogonoside are abundant in roots of Scutellaria baicalensis Georgi. It is reported that baicalin $(50,100$ or $150 \mathrm{mg} / \mathrm{kg}$ ) treatment significantly reduces interleukin (IL)-33 and NF-kBp65 levels, and increases ІкB $\alpha$ levels against the severity of $\mathrm{UC}$ in DSS-induced mice [45]. Moreover, treatment with baicalin (20 and $40 \mu \mathrm{mol} / \mathrm{L}$ ) obviously up-regulates expression of IL-4 and IL-10, increases ratio of p-STAT6/ STAT6, but decreases ratios of p-STAT4/STAT4 and $\mathrm{p}-\mathrm{NF}-\kappa \mathrm{B} / \mathrm{NF}-\kappa \mathrm{B}$ compared to the treatment of no baicalin in UC patients [46]. In addition, evidence indicates that wogonin $(25 \mathrm{mg} / \mathrm{mL})$ treatment obviously attenuates the inflammatory response of toll like receptor (TLR4)-myeloid differentiation factor (MyD) 88-mediated NF-kB pathway in lipopolysaccharide (LPS)-induced intestinal inflammation of Caco-2 cells in vitro, suggesting protective function on intestinal mucosal barrier [47]. As for wogonoside (12.5, 25 or $50 \mathrm{mg} / \mathrm{kg}$ ), its application inhibits the activation of NF-kB-induced NLRP3 inflammasomes in DSS-induced colitis and colitis-associated tumorigenesis in mice [48, 49].

Coptis chinensis Franch. has the highest use frequency for UC treatment. As a main ingredient of $C$. chinensis Franch., berberine $(100 \mathrm{mg} / \mathrm{kg})$ treatment inhibits the activations of NF- $\mathrm{kB}$ and mitogen-activated protein kinase (MAPK), which contributes to down-regulation of tumor necrosis factor (TNF), interferon gamma (IFN- $\gamma$ ) and IL-17 expressions in colonic macrophages and epithelial cells from DSS-induced mice, showing the reductions of crypt injury and severe inflammatory damage [50]. In addition, berberine $(100 \mathrm{mg} / \mathrm{kg}$ or $100 \mu \mathrm{M})$ treatment improves intestinal barrier function through suppression of the phosphorylated colonic signal transducer and activator of transcription (STAT) 3 and myosin light chain (MLC) kinase-MLC signaling pathway, as well as inhibition of IFN- $\gamma$ and TNF- $\alpha$ expressions and macrophage infiltration into the intestinal mucosa in DSS-colitis mice [51, 52].

As a derivative of coptisine, $( \pm)-8$-ADC $(75,150$, and $300 \mathrm{mg} / \mathrm{kg}$ ) treatment activates the transcriptional activity of X-box binding protein 1 and decreases NF- $\mathrm{kB}$ expression, subsequently reduces secretion of myeloperoxidase, TNF- $\alpha$, IL- 6 and IL- $1 \beta$ in the colon of DSS-induced colitis mouse. Over all, it significantly inhibits the development of colitis and improves the pathology associated with acute colitis induced by DSS [53].

Berberine hydrochloride is one of the effective compounds among Rhizoma Coptidis, Cortex Phellodendri, and other plants. Study has demonstrated that berberine hydrochloride (10, 30 and $50 \mathrm{mg} /$ $\mathrm{kg}$ ) treatment is able to suppress the expressions of phosphorylation of STAT3 and phosphorylation of NF-kBp65 which are induced by DSS in colonic tissues. Moreover, berberine hydrochloride treatment can effectively inhibit the activation of IL-6/STAT3/NF- $\mathrm{kB}$ in an experimental UC model in vivo, suggesting gut protective effects $[54,55]$.

As a constituent of Picrorhiza kurroathe, apocynin (control diet with $2 \%$ apocynin) treatment significantly reduces the activation of NF- $\mathrm{kBp} 65$ as well as STAT3 in DSS-treated colon tissues and the colitis induced by DSS in mice [56].

Matrine and oxymatrine are isolated from Sophora flavescens Ait. or Sophora subprostrata Chun et 
T.Chen. Studies suggest that in trinitrobenzene sulfonic acid (TNBS)-induced UC rats, matrine $(180 \mathrm{mg} / \mathrm{kg})$ treatment decreases the lesion area of inflammatory cell infiltration, edema and fibrosis and IL- $1 \beta$, TNF- $\alpha$, IL- 6 , IL-8 levels in colonic tissues. Kushenin injection (63 mg/ $\mathrm{kg}$ ) lows the overexpression of colonic mucosa proteins NOD2 and NF-kBp65 and decreases IL-6 secretion, which contributes to the attenuation of UC $[57,58]$. Oxymatrine $(63 \mathrm{mg} / \mathrm{kg})$ is found to reduce intestinal mucosa injury via up-regulation of the $\beta 2$-adrenoceptor and $\beta$-arrestin2 expressions and down-regulation of NF-кBp65 expression in colonic mucosa and spleen lymphocytes from TNBS-induced UC rats [59].

Ampelopsis grossedentata (AMP), which contains a large amount of flavonoid active compounds, has the traditional function of clearing heat and detoxification. AMP $(400 \mathrm{mg} / \mathrm{kg})$ exerts protective effects on DSSinduced UC via suppressing the IL-1 receptor associated kinase (IRAK1)/TNF receptor-associated factor 6 (TRAF6)/NF-KB-mediated inflammatory signaling pathway [60].

SM934 $(3,10 \mathrm{mg} / \mathrm{kg})$ is a water-soluble artemisinin analogue that shows significant attenuation of DSSinduced colonic inflammatory responses by suppressing the effects of macrophages and neutrophils and inhibiting the NF- $\mathrm{kB}$ signaling pathway [61]. Additionally, artesunate $(1030$, and $50 \mathrm{mg} / \mathrm{kg})$, a semi-synthetic derivative of artemisinin, exerts anti-inflammatory effects via regulating the TLR4-NF- $\kappa B$ signaling pathway in DSS-induced UC of rats [62].

Tetrandrine is a bisbenzylisoquinoline alkaloid extracted from the roots of Stephania tetrandra, and oral administration of tetrandrine $(65 \mathrm{mg} / \mathrm{kg})$ has distinct therapeutic effects on DSS-induced UC of mice, including inhibiting weight loss and improving diarrhea and blood stool. Its mechanism may be related to inhibition of the binding activity of NF- $\mathrm{kB}$ to DNA and down-regulation of the levels of TNF- $\alpha$ and IL- $1 \beta$ in colon tissue [63].

Evidence shows that Polygonum cuspidatum Siebold \& Zucc. (PCS) treatment can prevent DSS-caused weight loss and colon length reduction in UC mice, as well as increase the serum levels of IL-10 and reduce the levels of IL- $1 \beta$, IL- 6 and TNF- $\alpha$. Moreover, whatever PCSE $(100,200$ and $400 \mathrm{mg} / \mathrm{kg})$ or the combination of its three extractions: polydatin, resveratrol and emodin exhibit higher inhibitory activities for cytokines and NF- $\mathrm{kB}$ signaling related molecules than any one of the three compounds with same concentration treatment [64].

\section{Interior-warming and drying dampness medicine}

Aesculin is a main active compound of Aesculus chinensis Bunge with strong anti-inflammatory action. Aesculin $(1,5 \mathrm{mg} / \mathrm{kg})$ treatment can attenuate the activity of NF- $\kappa B$ signaling and promote the nuclear localization of peroxisome proliferator-activated receptor gamma (PPAR- $\gamma)$ in both rectal tissues from DSS-induced mice and LPS-stimulated macrophages, suggesting the protection of aesculin against UC might attribute to its regulation on the PPAR- $\gamma$ and NF- $\mathrm{kB}$ pathway [65].

Papaya [Chaenomeles speciosa (Sweet) Nakai] is either Chinese medicine or food. The main active compound of papaya, total triterpenoids of C. speciosa $(50,100 \mathrm{mg} /$ $\mathrm{kg}$ ) treatment can significantly reduce the levels of proinflammatory factors such as TNF- $\alpha$, IL- $1 \beta$, IL-6, IFN- $\gamma$, the ratios of $\mathrm{p}-\mathrm{IKK} \beta / \mathrm{IKK} \beta$ and $\mathrm{p}-\mathrm{I} \kappa \mathrm{B} \alpha / \mathrm{I} \kappa \mathrm{B} \alpha$, and nucleus NF-kBp65 in the colon tissue, while increase the levels of anti-inflammatory factors IL-4 and IL-10 in the blood, as well as the expressions of PPARy in the nucleus, SIRT1 in tissue and NF-kBp65 in cytoplasm, which contributes to the improvements of the general symptoms and pathological evolution of DSS-induced UC model mice [66].

Cardamonin is found in roots of Alpinia katsumadai Hayata. It $(1-50 \mathrm{mg} / \mathrm{kg})$ has been found to block nuclear translocation of NF-kBp65 in a mouse model of endotoxin shock, contributing to the attenuation of TNF- $\alpha$, IL- 6 and IL- $1 \beta$ secretions in LPS-induced mouse blood serum [67], and inhibit NF- $\kappa B$ DNA-binding in LPS-stimulated macrophage cells [68]. In acetic acidinduced colitis model, cardamonin (10 or $30 \mathrm{mg} / \mathrm{kg}$ ) treatment ameliorates the disease activity index (DAI) and macroscopic damage index scores, and reduces the levels of NF- $\kappa B$ and TNF- $\alpha$ as well as oxidative stress and apoptosis, evidencing it has a protective effect against acetic acid-induced colitis [69].

3, 4-Oxo-isopropylidene-shikimic acid (ISA) is a derivative of shikimic acid (a monomeric compound extracted from Illicium verum Hook.f.). In TNBSinduced colitis of rats, ISA $(50,100,200 \mathrm{mg} / \mathrm{kg}$ ) treatment not only exerts anti-oxidative and inhibits arachidonic acid actions, but also increases I $\mathrm{K} B \alpha$ protein expression and decreases NF- $\mathrm{kBp} 65$ protein expression in the colonic mucosa, showing significant therapeutic effects on experimental colitis in rats [70].

The main compounds of the chloroform extract of $\mathrm{Wu}$ Zhu Yu (WZY/Euodia rutaecarpa (Juss.) Benth.) are evodiamine and rutaecarpine. It shows that evodiamine $(80 \mathrm{mg} / \mathrm{kg}$ ) treatment notably improves body weight loss, DAI, colon length shortening and colonic pathological damage in DSS-induced UC mice, and decreases phosphorylation levels of NF- $\kappa$ Bp 65 and IкB and inhibits NLRP3 inflammasome activation in colonic tissues [71]. 
Flower bud and fruit of Clove (Eugenia caryophyllata Thumb.) are as medicinal application, and their main active compound is iridoid glycosides. Study evidences that iridoid glycosides $(80,160$ and $240 \mathrm{mg} / \mathrm{kg}$ ) have distinct therapeutic effects on TNBS-induced UC mice, embodying reduction of the protein and mRNA expressions of NF-kBp65, TNF $\alpha$ and IL-6 in the colon tissues [72]. Additionally, symptoms and weight loss present significant amelioration in mice induced by DSS under the treatment with syringic acid $(25 \mathrm{mg} /$ $\mathrm{kg}$ ) extracted from clove. What's more, its application decreases the expressions of NF- $\kappa B p 65$ and I $\mathrm{KB}$ in LPSinduced RAW 264.7 cells, thus reducing the activation and nuclear accumulation of p-STAT-3Y705, which contributes to inhibitions of ІкB degradation and the nuclear translocation of NF-kBp65 in colonic tissue [73].

In DSS-induced experimental mice colitis, it suggests that Zanthoxylum bungeanum pericarp extract (ZBE) $(0.5,1,2 \mathrm{~g} / \mathrm{kg})$ treatment alleviates body weight loss, colon length shortening and colonic pathological damage, whose mechanisms are related to inhibiting NF-kBp65 and ІкB $\alpha$ phosphorylation levels in a dose dependent manner and LPS-induced J774.1 cells. In addition, the suppression of NF- $\mathrm{kB}$ and MAPK pathways is partly attributed to the inhibition of their upstream TLR4 [74].

Research has found that galangin $(20$ and $40 \mathrm{mg} /$ $\mathrm{kg}$ ) isolated from Alpinia officinarum treatment either reduces the levels of nitrites, IL- 6 , and TNF- $\alpha$ in LPS-stimulated RAW 264.7 cells in a concentrationdependent manner, or decreases the levels of TNF- $\alpha$ and IL- 6 in colonic tissue and serum, as well as increases levels of anti-inflammatory cytokine (IL-10). Moreover, its application also suppresses protein expressions of $\mathrm{p}-\mathrm{NF}-\mathrm{kB}$ and $\mathrm{p}-\mathrm{Ikk}-\beta \alpha$ in colon tissues against inflammatory injury in mice [75].

\section{Detoxificating and purgative medicine}

Parthenolide is the main active compound of the genus Tanacetum parthenium. Studies reveal that parthenolide is used for the remedy of inflammatory diseases such as arthritis, asthma, and so on, and has been a potent inhibitor of NF- $\mathrm{KB}$ activation in cultured cells and experimental models. In DSS-induced mice UC, parthenolide $(5,10$ and $15 \mathrm{mg} / \mathrm{kg})$ is capable of inhibiting the secretions of TNF-a and IL- $1 \beta$ in colon tissue via blocking the phosphorylation and degradation of I $\mathrm{I} B \alpha$ and suppressing the phosphorylation of NF-kBp65, suggesting beneficial effects in experimental colitis [76]. Moreover, cotreatment with parthenolide and balsalazide $(20 \mathrm{ng} / \mathrm{mL})$ shows a significant inhibition in the TNF- $\alpha-$ induced phosphorylation of IkB- $\alpha$ and also blocks TNF$\alpha$-induced activation of p65 in HCT116 cells, suggesting that parthenolide enhances the effect of balsalazide on inhibition of NF- $\mathrm{kB}$ activation [77].

Research shows that arctigenin $(25,50 \mathrm{mg} / \mathrm{kg})$ derived from Arctium lappa L. treatment significantly suppresses the phosphorylated MAPKs and the activation of NF- $\mathrm{kB}$ by the inhibitions of phosphorylated IкB $\alpha$ and p65, p65 translocation and DNA binding activity. Simultaneously, its application markedly recovers the loss of intestinal epithelial cells, and decreases the infiltrations of neutrophils and macrophages and the secretion of inflammatory cytokines in DSS-induced UC mice [78].

Andrographolide is a natural antibiotic drug mainly existed in Andrographis paniculata (Burm. f.) Nees. It is reported that the andrographolide derivative AL-1 (andrographolide-lipoic acid conjugate) (5, 15 and $45 \mathrm{mg} / \mathrm{kg}$ ) treatment can attenuate the expression levels of $\mathrm{p}-\mathrm{I} \kappa \mathrm{B} \alpha, \quad \mathrm{p}-\mathrm{p} 65$ and cyclooxygenase-2 (COX2), and increase the expression of PPAR- $\gamma$, which contributes to reduction of colonic damage in TNBS-induced mice colitis [79]. In addition, another andrographolide $(200 \mathrm{mg} / \mathrm{kg})$ derivative CX-10, a semichemical synthesized by andrographolide, reduces the expressions of IL- 6 and TNF- $\alpha$ in colon tissue, as well as the expressions of NF-кBp65 and p-ІкB $\alpha$. Meanwhile its application increases the expression of ІкB $\alpha$ and suppresses the phosphorylated p38MAPK, extracellular regulated protein kinases (ERK) and c-Jun $\mathrm{N}$-terminal kinase (JNK). The significant effects ameliorate the colitis symptoms in DSS-induced UC mice [80].

Brusatol (BR) is one of the main active compounds of Brucea javanica (Linn.) Merr. It is reported that BR $(0.25$, $0.5,1 \mathrm{mg} / \mathrm{kg}$ ) treatment can inhibit the levels of proinflammatory cytokines and prostaglandin E2 (PGE2), and promote the production of immunoregulatory mediators like IL-4 and IL-10. Moreover, treatment with aqueous solution of BR significantly attenuates the expressions of TLR4, MyD88 and NF-kBp65 in colon tissue. It suggests that $\mathrm{BR}$ treatment is able to alleviate a certain degree of symptoms in mice with colonic inflammation by regulation of anti-inflammatory status [81]. Additionally, the ethyl acetate extract of the ripe fruit of B. javanica, brucea javanica oil (BJO) (0.5 1 and $2 \mathrm{~g} / \mathrm{kg}$ ) treatment reduces the body weight loss, restores the colon length and decreases the levels of TNF- $\alpha$, IL-1 $\beta$, IL-6, IL-8, IL-17 and IFN- $\gamma$ via the suppression of NF- $\mathrm{KB}$ pathway in DSS-induced mice [82].

Total flavonoids of Hedyotis diffusa Willd (50, 100, $200 \mu \mathrm{g} / \mathrm{mL}$ ) is reported to exert its anti-inflammatory activity via reducing pro-inflammatory nitric oxide, TNF$\alpha$, IL- 6 and IL- $1 \beta$ levels in LPS-stimulated RAW 264.7 cells through the suppressions of ІкB phosphorylation resulting in inactivation of NF- $\mathrm{kB}$ pathway and the phosphorylation of MAPK signaling pathway [83]. 
Moreover, administration of Oldenlandia diffusa (OD) $(1 \mathrm{~g} / \mathrm{kg})$ attenuates symptoms induced by DSS in mice, including the ameliorations of weight loss and colon length. Moreover, its application suppresses levels of IL-6, IL-1 $\beta$ and expression of COX2 in DSS-treated colon tissues, which is related to inactivation of NF-kBp65 in colon tissues [84].

Qing Dai (QD) is an extraction from leaves or stems of Strobilanthes cusia (Nees) Kuntze, Polygonum tinctorium Ait. and Isatis indigotica Fortune. Study has demonstrated that QD $(120,300$ or $600 \mathrm{mg} / \mathrm{kg})$ treatment distinctly improves the pathological degree of UC via increasing the mRNA expressions of IL-10 and IL-22 in lymphocytes [85]. Additionally, QD (0.77, 1.54 and $3.08 \mathrm{~g} / \mathrm{kg}$ ) treatment reduces DSS-induced macrophage infiltration and TNF- $\alpha$, IL-1 $\beta$, IL- 6 expressions in colonic tissues, and decreases TNF- $\alpha$, IL- 6 and COX-2 expressions via blocking LPS-induced ІкB $\alpha$ degradation and p65 nuclear translocation in RAW264.7 cells [86].

Indirubin is a compound extracted from Danggui Longhui Wan. It shows that indirubin $(10 \mathrm{mg} / \mathrm{kg})$ treatment obviously alleviates the symptoms and signs of DSS-induced UC in mice, and decreases inflammatory cell infiltration in the colon mucosa. Simultaneously, its application can regulate inflammatory cytokines, embodying the down-regulation of TNF- $\alpha$, IFN- $\gamma$ and IL-2 levels and up-regulation of IL-4 and IL-10 levels in colon tissues, which is related to inhibition of DSSinduced activation of NF- $\mathrm{kB}$ signaling [87].

Dandelion (Taraxacum mongolicum Hand.-Mazz.) contains various active compounds such as dandelion sterol, choline, inulin and pectin. Its pharmacological activities include anti-inflammatory, immune regulation, free radical scavenging, and anti-tumor. Evidence shows that aqueous dandelion root extract $(20 \mathrm{mg} / \mathrm{kg})$ has antiinflammatory effects on human colonic epithelial cells by increasing DSS-reduced cell viability and attenuating DSS-induced apoptosis, reactive oxygen species (ROS), and NF- $\mathrm{kB}$ signal activation [88].

Portulaca oleracea L., (POL) is one of commonly used medicinal-food herbs. Experimental results demonstrate that the ethanol extract from POL (100, 200 and $400 \mathrm{mg} /$ $\mathrm{kg}$ ) treatment increases the colon length, decreases body weight loss and reduces the mRNA expressions of TNF$\alpha$, IL- $1 \beta$ and IL- 6 and the protein expressions of TNF- $\alpha$ and NF-kBp65 in DSS-induced C57BL/6 mice UC model [89]. Additionally, therapeutic effects of portulaca extract $(100 \mathrm{mg} / \mathrm{kg})$ is similar to that of mesalazine, which presents reducing the expression levels of these cytokines including TNF- $\alpha$, IL- 6 , and IL- $1 \beta$ and the level of DSSinduced NF- $\mathrm{kB}$ phosphorylation [90].

Rhubarb-type anthraquinones are from Rheum palmatum L., Rheum tanguticum Maxim. ex Balf., or the dried roots and rhizomes of Rheum officinale Baill., including rhein, emodin, chrysophanol, and aloe emodin. Studies have shown that rhein $(1,5$ and $20 \mu \mathrm{M})$ treatment reduces nitric oxide (NO) production by suppressing the protein expressions of inducible nitric oxide synthase (iNOS) and COX-2, and its anti-inflammatory action is partially associated with reduction of the phosphorylation levels of NF- $\mathrm{kBp} 65$ and the suppression of NLRP3 expression in RAW264.7 macrophages [91]. It is reported that emodin $(5,10$ and $20 \mathrm{mg} / \mathrm{kg}$ ) treatment alleviates the symptoms and decreases the level of anti-flagellin in serum and suppresses the expressions of TLR5 and NF-kBp65 in colon of DSS-induced UC mice. Moreover, in vitro, emodin treatment inhibits the nuclear translocation of NF-kBp65 and decreases the release of IL-8 in flagellin-stimulated HT-29 cells via down-regulating the expressions of TLR5 and MyD88, up-regulating the expression of ІкB [92]. Chrysophanol $(5 \mathrm{mg} / \mathrm{kg}$ ) treatment decreases the activation of NF-kBp65 and caspase-1 in DSS-treated colon tissue and LPS-stimulated murine peritoneal macrophages, which contributes to attenuation of overall clinical scores and various pathological markers of colitis via against inflammatory injury [93].

Gallic acid (GA) is mainly isolated from rhizomes, dried leaves, and fruits of plants such as $R$. palmatum L., Eucalyptus robusta Sm. Research indicates that GA $(10 \mathrm{mg} / \mathrm{kg})$ treatment can attenuate the activation and nuclear accumulation of p-STAT3 (Y705), prevent the degradation of the inhibitory protein IKB, and inhibit the nuclear translocation of NF-kBp65 in colonic mucosa of DSS-exposed mice model against inflammatory response [94].

Allicin is a sulfur-containing compound naturally found in the bulbs of the lily plant Allium sativum L. It is reported that allicin $(10 \mathrm{mg} / \mathrm{kg})$ exerts anti-inflammatory effects through reduction of mRNA levels of TNF- $\alpha$, IL-1 $\beta$, IL-6 and IL-17, which is related to inhibiting activation and nuclear accumulation of STAT3 and preventing the inhibition of protein IкB degradation and inducing nuclear translocation of NF-kBp65 in colonic mucosa [95].

Study has found that treatment with Cassia obtusifolia (CO) $(1 \mathrm{~g} / \mathrm{kg})$ ameliorates signs including body weight loss and increased DAI, shortened colon length in DSS-induced colitis mice, as well as suppresses the levels of IL- 6 and expression of COX-2. Its therapeutic mechanism is associated with reduction of the activation of NF-kBp65 in colon tissues [96].

Bergenin isolated from the herb of Saxifraga stolonifera Curt alleviates disease symptoms of mice with DSSinduced colitis. Its mechanisms embody that bergenin $(20,50 \mathrm{mg} / \mathrm{kg})$ treatment activates PPAR $\gamma$, leading to 
increased expression of SIRT1. Subsequently, SIRT1 reduces the acetylation of NF- $\mathrm{kBp} 65$, up-regulates the association of NF- $\kappa B p 65$ and $\mathrm{I} \kappa \mathrm{B} \alpha$. Consequently, the nuclear translocation of NF- $\mathrm{kBp} 65$ is prevented resulting in reduced expressions of TNF- $\alpha$ and IL- 6 against inflammatory injury in DSS-induced mice [97].

Fagopyrum cymosum (Trev.) Meisn (Fag) (0.57, 1.14 and $2.28 \mathrm{~g} / \mathrm{kg}$ ) from Polygonaceae family is reported to inhibit the production of proinflammatory cytokines via inhibiting NF-kBp65 nuclear translocation and ІкB phosphorylation in TNBS-induced colitis model of rats. Furthermore, the clinical study results reveal that Fag has fewer side effects and serves as a better antiinflammatory potential drug for UC compared with salicylazosulfapyridine [98].

Chlorogenic acid from Chinese medicine honeysuckle, hawthorn, eucommia and chrysanthemum, has the ability to improve the expression of ERK1/2, p-ERK, p38, p-p38, JNK, and pJNK proteins in MAPK/ERK/JNK pathway in DSS-induced UC mice. Moreover, study has found that chlorogenic acid $(30,60$ and $120 \mathrm{mg} / \mathrm{kg}$ ) treatment can reduce or inhibit DSS-induced colonic mucosal damage, inflammation, oxidative stress, apoptosis and the phosphorylation level of IкB and NF-kBp65 protein in UC mice, thus inhibiting the activity of NF-kB [99].

\section{Blood-activating medicine}

Paeonol is the main active compound isolated from Moutan cortex. It is reported that paeonol enema $(100 \mu \mathrm{g} / \mathrm{mL})$ treatment improves the symptoms and pathology including body weight, colon length and histological score, and reduces TNF- $\alpha$-induced NF- $\mathrm{kB}$ transactivation and IFN $\gamma$-induced STAT1 transactivation in colon cancer-derived CW-2 cells and T cell leukemiaderived jurkat cells, suggesting paeonol enema may be useful for the treatment of colitis [100].

As main bioactive compound extracted from Sargentodoxa cuneata, Liriodendrin (100 $\mathrm{mg} / \mathrm{kg})$ treatment distinctly improves DAI, colon length and histological damage in colon and suppresses the levels of TNF-a, IL-1 $\beta$ and IL- 6 and the activation of Akt and NF- $\mathrm{kB}$ pathways, and up-regulates the expression of ER $\beta$ in the colon of DSS-induced mouse colitis model. Simultaneously in vitro, liriodendrin treatment downregulates production of pro-inflammatory cytokines and suppresses NF- $\mathrm{KB}$ signaling pathways in LPS-induced RAW 264.7 macrophages [101].

Shikonin is a purple flaky crystal or crystalline powder. It is the main active compound in the roots of Lithospermum erythrorhizon Sieb. et Zucc. Its pharmacological effects include anti-cancer, antiinflammatory and antibacterial. Shikonin $(6.25,12.5$ and $25 \mathrm{mg} / \mathrm{kg}$ ) shows obvious therapeutic actions on
DSS-induced acute colitis in Balb/C mice. Its application notably reduces the amount of $\mathrm{CD} 4+$ lymphocytes and macrophages in the colon tissue of mice, and the release of pro-inflammatory factors such as TNF- $\alpha$, IL- $1 \beta$, and IL- 6 production. In addition, shikonin treatment also reduces the expressions of COX-2 and NF-kBp65, and phosphorylation of STAT-3 in IBD model [102].

Tetramethylpyrazine (TMP), also known as ligustrazine, is the main active compound purified from Ligustium wollichii franchat. It is found that TMP $(80 \mathrm{mg} / \mathrm{kg}$ ) treatment attenuates the damage caused by intrarectal instillation of oxazolone (OXZ) and substantially reduces the rise in TNF- $\alpha$ and NF- $\mathrm{kBp} 65$ expressions, and increases PPAR- $\gamma$ production in colitis mice [103].

Crocetin is a constituent of saffron (Crocus sativus). Evidence indicates that crocetin $(50 \mathrm{mg} / \mathrm{kg})$ treatment improves diarrhea and the disruption of colonic architecture in TNBS-induced mice colitis model, and inhibits IL-12 production through the down-regulation of NF-kB-mediated activation and enhances IL-4 in CD4 $+\mathrm{T}$ cells, showing useful supplement therapy for UC [104].

Epicatechin is widely found in plants such as Acacia catechu (L.f.) Willci. Epicatechin. Study indicates that the doses of 100,200 or $300 \mathrm{mg} / \mathrm{kg}$ can alleviate the DAI and colon macroscopic damage index scores, reduce body weight loss, and significantly relieve colon contracture and crypt damage in DSS-induced acute UC mice model, and reduce TNF- $\alpha$, IL- 6 and inhibit NF-kB pathway in vivo and in vitro [105]. Another similar component, (2)-epigallocatechin-3-gallate (EGCG), has inhibited effect on NF-KB nuclear translocation in IEC-6 cells of UC patients by the inactivation of ІкB kinase [106].

Curcumin is a natural hydrophobic polyphenol, a compound mainly extracted from the rhizome of the ginger family C. longa L. [107], and exerts multiple pharmacological effects on IBD [108, 109]. Curcumin $(100 \mathrm{mg} / \mathrm{kg}$ or $15,30,60 \mathrm{mg} / \mathrm{kg})$ treatment not only down-regulates expression of pro-inflammatory cytokines, such as IL-1, IL-6, IL-8, and TNF- $\alpha$ by regulating $\mathrm{NF}-\mathrm{kB} / \mathrm{IkB}$ pathway, reduces inflammatory cell infiltration in several experimental models of UC, but also suggests clinical remission in active mild-tomoderate UC patients and reduces clinical relapse in quiescent UC patients [110-112].

\section{Qi-regulating medicine}

Norisoboldine (NOR), the main active compound of Radix Linderae, indicates that the doses of 20, $40 \mathrm{mg} / \mathrm{kg}$ markedly reduce the symptoms of colitis and inhibit phosphorylations of ERK and p38MAPK, and phosphorylation, nuclear translocation and 
DNA-binding activity of NF-kBp65 in colons of UC mice, which might offer a reasonable explanation for inhibition of pro-inflammatory cytokines by NOR [113].

Research reveals that Citrus aurantium L. and its flavonoids (Naringenin, nobiletin, and hesperetin) (125, 250 and $500 \mathrm{mg} / \mathrm{kg}$ ) suggests anti-inflammatory effects on TNBS-induced IBD and LPS-induced RAW cells, which is related to the inhibition of TNF- $\alpha$-induced NF-kB pathway [114].

\section{Tonifying medicine}

Study shows that inhibitory effects of Eclipta Prostrata (EP) $(500 \mathrm{mg} / \mathrm{kg})$ on DSS-induced UC occurrence by improving body weight loss, shortened colon length and DAI, and reducing the phosphorylation of IкB and the translocation of the NF- $\mathrm{kB}$. Additionally, a HPLC analysis shows that wedelolactone, contained in water extract of $\mathrm{EP}$, is an inhibitor of NF- $\mathrm{kB}$ transcription [115].

Astragalus polysaccharide (APS) and astragaloside IV (ASI) are extracts of Astragalus membranaceus. Study reveals that APS $(200 \mathrm{mg} / \mathrm{kg})$ treatment increases weight and colon length and reduces NF- $\mathrm{kB}$ DNA phosphorylation activity and down-regulates TNF$\alpha$, IL-1 $\beta$, IL-6, IL-17 expressions associated with improvement in DSS-induced mice colitis [116]. In addition, ASI $(200 \mathrm{mg} / \mathrm{kg})$ treatment reverses the increase of TNF- $\alpha$, IL- $\beta$ and IL- 6 inflammatory cytokine via the inhibition of the NF- $\kappa B$ pathway in LPS-stimulated CCD-18Co cells. In DSS-induced UC mice, except for the inhibition of pro-inflammatory cytokines, ASI treatment also decreases the level of p-p65 and p-IкB proteins, suggesting effective amelioration on experimental UC in vitro and in vivo [117].

Licochalcone A (Lico A) is a characteristic chalcone existing in licorice root, which is widely used in Chinese medicine formulae. The results show that Lico A (20, 40 and $80 \mathrm{mg} / \mathrm{kg}$ ) treatment reduces the colon length, histological damage scores and MPO activity, and decreases the oxidative stress and pro-inflammatory cytokines, down-regulates NF- $\mathrm{kB}$ pathway and up-regulates Nrf2 pathway in DSS-induced UC [118]. Furthermore, as a substance extracted and purified from Glycyrrhiza uralensis Fisch, diammonium glycyrrhizinate $(40 \mathrm{mg} / \mathrm{kg}$ ) treatment is found to reduce inflammatory injury in a rat model of UC via suppressions of NF- $\mathrm{KB}$ and TNF- $\alpha$ in colonic mucosa [119].

Vanillic acid (VA) is a well-known flavonoid, which possesses various pharmacological activities such as anticolitis, anti-mutagenic, anti-angiogenetic, anti-sickling, and anti-analgesic effects, and there is a large amount of VA in the roots of Angelica sinensis (Oliv.) Diels. Studies show that VA $(200 \mathrm{mg} / \mathrm{kg})$ treatment suppresses the activation of NF-kBp65 transcription in DSS-treated colon tissues and the level of IL-6, which contributes to relieving the severity of the clinical signs, including weight loss, shortening of colon length and the DAI [120].

Paeoniflorin (PA) is the main bioactive compound of Paeony root, it can be extracted from the dried peeled root of Paeonia lactiflora Pall. In recent study, oral administration of PA $(15,30$ and $45 \mathrm{mg} / \mathrm{kg})$ exhibits the protective effect on TNBS-induced UC mice by inhibiting MAPK/NF- $\kappa B$ pathway and suppressing the expressions of IL-2, IL-6, IL-10, IL-12, IL-1 $\beta$, TNF- $\alpha$ and IFN- $\gamma$, showing PA is a novel therapeutic agent in the treatment of UC [121].

The fruit of Ziziphus jujuba Mill. (Rhamnaceae) has been widely used as food and Chinese medicines for over 3000 years, and described as one of the five most valuable fruits in China. Research reveals that dietary Z. jujuba (ZJ) fruit $(5 \%$ or $10 \% \mathrm{w} / \mathrm{w})$ treatment decreases fecal blood, diarrhea and DAI, and attenuates the expression of proteins in the NF- $\mathrm{kB} / \mathrm{IL}-6 / \mathrm{JAK} 1 / \mathrm{STAT} 3$ signaling pathway involved in inflammation associated with colorectal cancer in mice, suggesting anti-inflammatory property of ZJ [122].

Pretreatment of oligonol (10, 50 and $100 \mathrm{mg} / \mathrm{kg}$ ) extracted from fruit lychee is reported to notably ameliorate pathological changes and decrease the levels of IL-1, IL-6, and TNF- $\alpha$ as well as NF- $\mathrm{kB}$ in affected colon tissues of DSS-induced UC model [123].

It is reported that Lentinus edodes $\beta$-glucans (500 and $1000 \mathrm{mg} / \mathrm{kg}$ ) treatment can increase the body weight, improve DAI and modify p38MAPK and ERK $1 / 2$ in DSSinduced UC mice, and then phosphorylate PPAR $\gamma$, which negatively regulates activation of NF- $\mathrm{KB}$ [124].

Study has showed that mango (Mangifera Indica L.) extract $(10 \mathrm{mg} \mathrm{GAE} / \mathrm{L})$ treatment is against DSSinduced colonic inflammation and decrease NF- $\mathrm{kB}$ and iNOS mRNA levels, as well as NF- $\kappa \mathrm{B}$ and p-NF- $\mathrm{kB}$ protein levels in rats. In addition, mango polyphenolics treatment attenuates the levels of inflammatory markers via suppression of the PI3K/AKT/mTOR signaling pathway, in part through up-regulation of miRNA-126 in DSS-induced colonic inflammation [125].

\section{Astringent medicine}

Experiment shows that the activity of NF-kBp65 decreases in the colon tissue of UC female rats induced by intracolonic injection of iodoacetamide after rectal administration of muscovite treatment (360 and $720 \mathrm{mg} /$ $\mathrm{kg}$ ), which contributes to the reduction of IL- 8 and TNF- $\alpha$ concentrations, as well as the improvements of body weight, macroscopic damage and microscopic score [126]. 
Shan $\mathrm{Zhu} \mathrm{Yu}(\mathrm{SZY})$ is a dry mature flesh of the Cornus officinalis Sieb. et Zucc. Studies evidence that SZY (1, $10,100 \mu \mathrm{M}$ or $0-50 \mathrm{mg} / \mathrm{mL}$ ) treatment attenuates TNF$\alpha$-induced NF-кBp65 translocation and LPS-stimulated phosphorylation and degradation of $\mathrm{I} \kappa \mathrm{B} \alpha$ and the subsequent translocation of the p65 subunit of NF- $\mathrm{kB}$ to the nucleus in human umbilical vein endothelial cells and RAW 264.7 macrophage cells, respectively [127, 128]. Moreover, the isolated ursolic acid (10 and $20 \mathrm{mg}$ / $\mathrm{kg}$ ) treatment in the ethanol extract of $C$. officinalis seed inhibits phosphorylation of inhibitor of NF- $k B$ kinase subunit $\beta$ (IKK $\beta$ ) and $I \kappa B \alpha$ and activation of NF- $N B$ and MAPKs in LPS-stimulated macrophages, as well as suppresses LPS-stimulated IL-1 $\beta$, IL-6, TNF- $\alpha$ levels. Oral administration of ursolic acid significantly inhibits TNBS-induced colon shortening, and suppresses NF- $k B$ activation in colon tissues and IL- $1 \beta$, IL-6, TNF- $\alpha$ levels, but enhances IL-10 levels [129].

The main active compound of Rubus coreanus is 19a-hydroxyursane saponin. The $R$. coreanus triterpenoid compound is separated and purified from $R$. coreanus by various columns, and the structure is identified according to the physical and chemical properties and spectral data. It is found that the administration of triterpenoid component (TFRC) $(25,50$ or $100 \mathrm{mg} / \mathrm{kg})$ in $R$. coreanus improves the pathological characteristics including colon shortening and colonic epithelium injury, and reduces the expression of pro-inflammatory factors IL-1 $\beta$, IL- 6 and TNF-a protein and mRNA and macrophages infiltration into colon tissue in DSS-induced mice of acute UC, whose mechanisms might be related to down-regulations of NF- $\mathrm{kB}$ and $\mathrm{p} 38 \mathrm{MAPK}$ signaling [130]. Furthermore, $R$. coreanus extracts (ethanol and water extracts) $(400 \mu \mathrm{g} /$ $\mathrm{mL}$ ) treatment obviously reduces NF- $\mathrm{kB}$ activation and JNK and p38 phosphorylation in LPS-induced RAW 264.7 cells [131].

Osthole is an active compound isolated from the fruit of Cnidium monnieri (L.) Cuss. Experiment data reveals that DSS triggers the degradation of IкB $\alpha$ and increases the protein expression of NF- $\kappa B p 65$ and $\mathrm{p}-\mathrm{I} \kappa \mathrm{B} \alpha$ in UC mice, but after treatment with osthole $(10,20,40 \mathrm{mg} /$ $\mathrm{kg}$ ), the expressions of NF-kBp65 and $\mathrm{p}-\mathrm{I} \mathrm{kB} \alpha$ decrease, and expression of $\mathrm{I} \kappa \mathrm{B} \alpha$ increases. Therefore, osthole treatment can relieve the symptoms of UC by inhibiting weight loss, colon shortening, and the DAI score, and blocking the up-regulation of TNF- $\alpha$ in serum and colon tissues by inhibiting the activation of NF- $\mathrm{KB}$ pathway [132].

\section{Chinese Medicine formulae targeting NF-KB pathway for UC treatment}

The formulae consists of multi-Chinese medicinals and exerts synergistic effects according to the Chinese medicine therapeutic pillars based on syndrome differentiation. By focusing on the traditional functions of the formulae targeting NF- $\mathrm{KB}$ pathway for UC treatment, we categorized these formulas into five types.

\section{Tonifying Qi and activating blood category}

Shen Ling Bai Zhu San (SLBZS) is one of the most popular formulae of Chinese medicine for the treatment of UC. It is composed of 10 herbs, and has been proven to have wide pharmacological effects on digestive diseases, including anti-inflammatory and gut microbiota modulation actions. In recent study, researchers apply the systems pharmacology method to explore the pharmacological mechanisms of SLBZS, and found the changes of IL-1 $\beta$, IL-10, and TNF- $\alpha$ after SLBZS treatment $(0.6 \mathrm{~g} / \mathrm{mL})$. IL- $1 \beta$ and TNF- $\alpha$ participated in the MAPK and NF- $\mathrm{kB}$ pathways, and the two pathways share crosstalk in DSS-induced UC rats [133].

Tou Nong San (TNS), a Chinese medicinal decoction used for treating sores and carbuncles, has a positive effect on the inflammation. TNS (3.3, 6.6 and $13.2 \mathrm{~mL} /$ $\mathrm{kg}$ ) treatment leads to improvements in weight loss and water and food intake in rats. Moreover, the macroscopic and microscopic scores of rat tissues greatly decrease. Apart from that, protein and mRNA levels of proinflammatory cytokines, IL-17, TNF- $\alpha$, IL- $1 \beta$, and IL-6, involved in the NF- $\mathrm{kB}$ signaling pathway notably decrease in TNBS-induced IBD [134].

\section{Heat-clearing and drying dampness category}

Shaoyao decoction is a Chinese medicinal formula consisted of 9 herbs. Study shows that the dose of $7.12 \mathrm{~g} /$ $\mathrm{kg}$ increases the survival rate of DSS-induced UC mice and attenuates the expression levels of serum IL-1 $\beta$, IL- 6 , TNF- $\alpha$ and NF- $\kappa B$ activation [135].

It suggests that Qingchang Huashi granule (QCHS) $(2.8,5.5$ and $11.0 \mathrm{~g} / \mathrm{kg})$ treatment inhibits the damage of colon length and ameliorates the inflammatory response by decreasing concentrations of the cytokines IL- $1 \alpha$, IL- 6 , IL- 8 , IL- $1 \beta$, and TNF- $\alpha$ and increasing the concentrations of IL-4, IL-10, and IL-13 in TNBS-induced rat UC model [136]. In vitro, in TNF- $\alpha$ and LPS induced HT-29 cells, Qingchang Huashi Recipe (100 ng/mL, 1 and $10 \mu \mathrm{g} /$ $\mathrm{mL}$ ) treatment reduces the activation of NF- $\mathrm{kB}$, lows the expressions of TLR4 protein and the secretion of IL- 8 [137].

Study shows that administration of effective compounds alignment of Gegenqinlian decoction (GQD) $(0.12 \mathrm{~g} / \mathrm{kg})$ is able to improve TNBS-induced colonic 
injury, which is related to significant reduction of TNF- $\alpha$ and IL- $1 \beta$ levels in colon and serum, as well as inhibiting the activation and translocation of NF- $\mathrm{kp} 65$ in colon [138]. Additionally, it indicates that oral administration of GQD $(0.3,1.5$ or $7.5 \mathrm{~g} / \mathrm{kg})$ alleviates the severity of colitis in DSS-induced UC mice model, and reduces TLR4 expression and NF- $\mathrm{kB}$ activation in mucosa, which accompanies with down-regulations of TNF- $\alpha$, IL-6, IL-1 $\beta$ and IL-4 in the colon [139].

Jianpi Qingchang decoction (JPQCD) is a Chinese medical prescription that consists of nine Chinese herbs, namely, Astragalus, Codonopsis pilosula, Portulaca oleracea, Sanguisorba officinalis, Notoginseng, Bletilla striata, Radix Aucklandiae, and Licorice. It is reported that JPQCD $(17.1 \mathrm{~g} / \mathrm{kg})$ treatment reduces the mRNA levels of IL-1 $\beta$, IL-8, TNF- $\alpha$ and NF- $\mathrm{BB}$ in DSSinduced UC mice, suppresses activation of NF- $\mathrm{KB}$ and increases phosphorylation of IkB [140]. Using systems pharmacology to predict the active ingredients, it shows that 170 targets for the 107 active ingredients of JPQC and 112 candidate targets of UC, and JPQC treatment can improve the mucosal inflammatory response and intestinal epithelial barrier function via the $N F-\kappa B /$ HIF-1 $\alpha$ signaling pathway [141].

Active compounds from modified pulsatilla decoction (MPD) have shown hepatic protective, anti-inflammatory, antibacterial, antitumor and anti-oxidant effects. In addition, MPD $(10 \mathrm{mg} / \mathrm{g}$ body weight) treatment attenuates the severity of colitis, and suppresses the activation of the NF- $\mathrm{KB}$ signaling pathway in OXZ-induced colitis mice model, and reduces the secretion of pro-inflammatory cytokines and restores alterations in tight junction proteins in the colon tissues, showing MPD offers an effective therapeutic approach for the treatment of UC [142].

Qing Hua Chang Yin (QHCY) has been used for many years to treat conditions associated with IBD, such as UC. Moreover, QHCY $(1.4 \mathrm{mg} / \mathrm{mL})$ treatment profoundly ameliorates DSS-induced manifestations, colon shortening and histological damage in colitis mice. Moreover, its application significantly inhibits the DSS-induced expression of TLR4 and MyD88, the phosphorylation of IKB and the nuclear translocation of NF-kB. Taken together, it suggests that the suppression of the TLR4/NF- $\mathrm{kB}$ signaling pathway may be one of the mechanisms involved in the therapeutic effects of QHCY against UC [143]. Furthermore, QHCY (1.4 mg/mL) treatment attenuates the LPS-induced phosphorylation of JAK1 and JAK2 in differentiated Caco-2 cells, which is in accordance with the reduced phosphorylation state of STAT3. It indicates that QHCY treatment inhibits the phosphorylation of STAT3, possibly through the inactivation of JAK1 and JAK2 in LPS-induced inflammatory responses [144].

QingBai decoction (QBD) has been applied for the treatment of IBD patients in clinic. Research indicates that QBD $(0.0195 \mathrm{~mL} / \mathrm{g})$ treatment effectively alleviates intestinal inflammation and mucosal barrier function in colitis mice, and reduces the production and secretion of serials pro-inflammatory cytokines such as L-1 $\beta$, IL-6, and TNF- $\alpha$ in DSS-induced colitis. Moreover, QBD treatment decreases the intestinal permeability and inflammatory cascade by inhibiting NF- $\mathrm{KB}$ signaling [145].

Oral administration of Chang-An-Shuan (CAS, a 6-herb Chinese medicinal formula) at 0.5 or $5 \mathrm{~g} / \mathrm{kg} /$ day ameliorates the severity of TNBS-induced colitis as evidenced by the reduced loss of body weight, alleviated diarrhea and decreased bloody stool in rats. More important, the ameliorative effects of CAS are related to the inhibition of NF- $\mathrm{kB}$ signaling pathway by downregulating the expression levels of NF-kBp65, p-38 and p-AKT [146].

Baishaoqiwu (BSQW) is a formula consisting of 7 Chinese herbal medicines. Study shows that BSQW (13.2 $\mathrm{mg} / \mathrm{kg})$ treatment ameliorates TNBS-induced macroscopic and histological damage in the rats with induced colitis, and distinctly inhibits TNBS-induced expression of TLR4, MyD88 and NF-кBp65 genes. No treatment-related toxicity is found in the BSQWtreated group [147].

Recent results indicate that oral treatment with xie-xin decoction ( 2 or $4 \mathrm{~g} / \mathrm{kg}$ ) for 8 days promotes the recovery of colitis and inhibits the inflammatory response, including amelioration of macroscopic and histological examination, the enhanced level of IL-10, and the decreased expressions of TNF- $\alpha$ and NF- $\mathrm{kBp} 65$ in rats with experimental UC [148].

Compound sophorae decoction (CSD), consisted of 6 Chinese herbal medicines, is effective for the clinical treatment of UC. The aqueous extract of CSD (7.28 g/ $\mathrm{kg}$ ) treatment is able to improve the symptoms and pathological damage of DSS-induced UC mice, which is related to reducing the levels of IL- $1 \beta$, TNF- $\alpha$ and phospho-NF-кBp65 and regulating Th17/Treg cell balance [149].

Huangkui Lianchang decoction (HLD) is a Chinese medicinal cocktail used to treat UC. Study indicates that $\operatorname{HLD}(9.425,18.85,37.70 \mathrm{~g} / \mathrm{kg})$ treatment alleviates colonic pathological damage in DSS-induced UC mice, and decreases IL- 6 , TNF- $\alpha$, and IL- $1 \beta$ levels via the inhibition of the NF-kB pathway [150].

Study shows that the expressions of TLR4 and NF-kBp65 in colon tissues of UC patients obviously decrease in Bawei Xilei Powder (BXP) group compared 
with control group treating with hydrocortisone enema solution. BXP enema treatment $(1 \mathrm{~g} / 60 \mathrm{~mL})$ is effective and safely applied in patients with mild to moderate UC, and its mechanisms might be involved in suppressing inflammatory response and enhancing mucosa barrier functions [151].

\section{Harmonizing cold and hot category}

Ban-xia-xie-xin decoction (BXD) $(8.7 \mathrm{~g} / \mathrm{kg})$ treatment against DSS-induced chronic UC injury in mice is characterized by amelioration of body weight loss, DAI and histology score, as well as decreasing the levels of TNF- $\alpha$, IL-1 $\beta$, IL-17, IL-23, COX-2 and p-p65 and increasing the level of IL-10. The protective mechanism of BXD may associate with inhibition of NF- $\mathrm{kBp} 65$ activation and enhancement of $\mathrm{Nrf} 2$ expression in colorectums of mice [152].

It is reported that wu-mei-wan (WMW) $(0.515 \mathrm{~g} /$ $\mathrm{mL}$ ) treatment up-regulates the expression of IL-10, down-regulates the expressions of TNF- $\alpha$, IL-6, IL-8, and inhibits the NF-kBp65 activity to adjust immune function, showing WMW has better therapeutic effects on UC in rats [153].

\section{Warming yang and drying dampness category}

Study shows that modified ZenWu decoction (MZWD) $(17.47 \mathrm{~g} / \mathrm{kg})$ treatment notably reduces diarrhea, bloody stool and colon shortening and improves mucosal integrity, and suppresses inflammatory responses namely inhibiting immune-cell infiltration and serum levels of pro-inflammatory cytokines in DSS-induced experimental colitis mice. Furthermore, MZWD treatment attenuates the activation of NF- $\mathrm{kB}$ via lessening the degradation of IKB $\alpha$ in colonic tissues [154].

Ping weisan $(2,4,8 \mathrm{~g} / \mathrm{kg})$ treatment is reported to decrease DSS-induced DAI, colon length shortening and colonic pathological damage, and reduce TNF- $\alpha$, IL- $1 \beta$ and IL- 12 secretions and suppress NF-kB pathway activation by regulating the expressions of TLR4 and PPAR $\gamma$ in DSS-induced chronic colitis in mice, indicating the formula might be a novel agent for the treatment of chronic colitis [155].

\section{Astringent category}

Recent results indicate that oral treatment with zhenrenyangzang decoction $(2,4$ or $8 \mathrm{~g} / \mathrm{kg}$ ) notably promotes the recovery of colitis which embodies the improvement of DAI and tissue damage scores in TNBSinduced UC rats, and inhibits the inflammatory response by reducing the mRNA or protein expressions of NF- $\mathrm{kB}$ and p38MAPK, as well as the production of TLR2 in colon tissues. The study provides direct pharmacological evidence for zhenrenyangzang decoction clinical application [156].

\section{Direct and indirect regulatory efficacies of Chinese medicines targeting NF-KB for UC treatment}

Numerous literature have demonstrated that Chinese medicines targeting NF- $\mathrm{kB}$ play a vital role in UC treatment. In present study, it suggests Chinese medicines with different traditional functions exert direct and indirect regulatory efficacies on NF-kB pathway in different pathological models of UC. The definitions of direct and indirect regulatory efficacies respectively refer to action on NF- $\mathrm{kBp} 65$ and influence on NF- $\mathrm{kB}$ pathway via NF-kBp65's up-stream or other signaling pathways.

\section{Direct inhibition of Chinese medicines targeting NF-KB}

According to Chinese medicinal traditional functions, we summarize Chinese medicines that directly inhibit the activation of NF- $\mathrm{kB}$ characterized by decreasing NF-kBp65 levels, reducing the nuclear translocation of NF-kBp65 or up-regulating NF- $k B p 65$ in cytoplasm in Table 1.

\section{Indirect regulation of Chinese medicines targeting NF-KB} Apart from direct inhibited effect, Chinese medicines can indirectly regulate NF- $\mathrm{kB}$ pathway as well. For example, Chinese medicines increase $\mathrm{I} \kappa \mathrm{B} \alpha$ levels, inhibit ІкB protein phosphorylation or modulate the association between NF- $\mathrm{KBp} 65$ and $\mathrm{I} \kappa \mathrm{B} \alpha$, as well as act on other signaling pathways to influence the activation of NF- $\kappa B$ pathway in pathogenic mechanisms of UC [157]. Based on Chinese medicinal traditional functions, we summarize Chinese medicines indirectly regulate NF- $\mathrm{kB}$ pathway in Table 2.

\section{Conclusion}

In terms of direct inhibition of NF- $\mathrm{kB}$ in the treatment of UC, we summarized 85 kinds of Chinese medicines and their active compounds, as well as formulae. By analysis, we find that four categories of heat-clearing and dampness-drying medicine, interior-warming and drying dampness medicine, detoxificating and purgative medicine and tonifying medicine account for primary status, which embodies prevention of phosphorylated and nuclear transcriptional NF-kBp65 or enhancement of the level of p65 in the cytoplasm. Simultaneously, we also discover that the number of formulae with function of heat-clearing and drying dampness targeting direct inhibition of NF- $\mathrm{KB}$ is maximum.

On the other hand, we summarized 58 Chinese medicines and their active compounds, as well as formulae for indirect inhibition of NF-kB. Among them, the categories of heat-clearing and dampness-drying 


\section{Table 1 Direct inhibited efficacy of Chinese medicines on NF-KB pathway}

\begin{tabular}{|c|c|c|c|c|}
\hline Classifications & Chinese medicines & Models & Mechanisms & References \\
\hline \multirow{20}{*}{$\begin{array}{l}\text { Heat-clearing and } \\
\text { dampness-drying } \\
\text { medicine }\end{array}$} & Casticin & RAW264.7 & Repress the NF-kBp65 nucleus translocation & {$[44]$} \\
\hline & \multirow[t]{2}{*}{ Baicalin } & DSS-induced colon tissue & $\begin{array}{l}\text { Reduce the protein levels of NF-kBp65 and } \\
\text { p-NF-kBp65 }\end{array}$ & {$[45]$} \\
\hline & & UC patients & Decrease ratios of $\mathrm{p}-\mathrm{NF}-\mathrm{kB} / \mathrm{NF}-\mathrm{kB}$ & {$[46]$} \\
\hline & Wogonin & Caco-2 cells & Decrease NF-kB activity & [47] \\
\hline & \multirow[t]{3}{*}{ Wogonoside } & DSS-induced colon tissues & $\begin{array}{l}\text { Inhibit nuclear translocation of NF-KBp65, } \\
\text { phosphorylated p65 and NF-KB DNA binding } \\
\text { activity }\end{array}$ & {$[48]$} \\
\hline & & $\begin{array}{l}\text { AOM/DSS-induced tumor } \\
\text { tissues }\end{array}$ & Inhibit the protein expression of p-p65 & {$[49]$} \\
\hline & & THP-1 cells & Suppress NF-kB nuclear translocation & {$[49]$} \\
\hline & Berberine & $\begin{array}{l}\text { Colonic macrophages and } \\
\text { epithelial cells }\end{array}$ & Inhibit activation of NF-kB & {$[50]$} \\
\hline & \multirow[t]{2}{*}{$( \pm)-8-A D C$} & DSS-induced colon tissues & $\begin{array}{l}\text { Reduce phosphor-NF-kBp65 expression; } \\
\text { Decrease the NF-kB mRNA expression }\end{array}$ & {$[53]$} \\
\hline & & IEC6 Cells & Reduce phosphor-NF-KBp65 expression & [53] \\
\hline & Berberine hydrochloride & DSS-induced colonic tissues & $\begin{array}{l}\text { Suppress the expressions of phosphorylation of } \\
\text { NF-kBp65 }\end{array}$ & {$[54,55]$} \\
\hline & Apocynin & DSS-induced tissues & Reduce the activation of NF-kBp65 & {$[56]$} \\
\hline & Matrine & TNBS-induced colonic mucosa & Reduce the overexpression of NF-kBp65 & {$[58]$} \\
\hline & Oxymatrine & TNBS-induced colon mucosa & Down-regulate the expression of NF-kBp65 & {$[59]$} \\
\hline & $\begin{array}{l}\text { Ampelopsis } \\
\text { grossedentata }\end{array}$ & DSS-induced colon tissues & Suppress the NF-KB activation & {$[60]$} \\
\hline & \multirow[t]{2}{*}{ SM934 } & DSS-induced colon tissue & Decrease phosphorylation of NF-kB & {$[61]$} \\
\hline & & Macrophages & $\begin{array}{l}\text { Suppress phosphorylation of NF-kBp65; Inhibit } \\
\text { NF-kB nuclear translocation }\end{array}$ & {$[61]$} \\
\hline & Artesunate & RAW264.7 cells & Reduce the expression levels of $\mathrm{p}-\mathrm{NF}-\mathrm{kB}$ & {$[62]$} \\
\hline & Tetrandrine & DSS-induced colon tissue & Inhibit the binding activity of NF-KB to DNA & {$[63]$} \\
\hline & $\begin{array}{l}\text { Polygonum cuspidatum } \\
\text { Siebold \& Zucc. }\end{array}$ & DSS-induced colon tissue & Suppress the NF-kB & {$[64]$} \\
\hline \multirow{11}{*}{$\begin{array}{l}\text { Interior-warming and } \\
\text { drying dampness } \\
\text { medicine }\end{array}$} & Aesculin & RAW264.7 cells & Inhibit p-NF-kBp65 levels in nucleus & {$[65]$} \\
\hline & $\begin{array}{l}\text { Total triterpenoids of } \\
\text { Chaenomeles speciosa }\end{array}$ & DSS-induced colon tissue & $\begin{array}{l}\text { Down-regulate the protein expressions of } \\
\text { nucleus NF-kBp65, up-regulate the protein } \\
\text { expressions of cytosol NF-kBp65 }\end{array}$ & {$[66]$} \\
\hline & \multirow[t]{2}{*}{ Cardamonin } & RAW264.7 cells & $\begin{array}{l}\text { Prevent the nuclear accumulation of NF-kBp65; } \\
\text { Block the translocation of NF-kBp65 }\end{array}$ & {$[67]$} \\
\hline & & AA-induced colon tissue & Reduce the levels of NF-KB & {$[69]$} \\
\hline & $\begin{array}{l}\text { 3,4-Oxo-isopropylidene- } \\
\text { shikimic acid }\end{array}$ & TNBS-induced colon tissues & Decrease NF-kBp65 subunit level & {$[70]$} \\
\hline & Wu Zhu Yu & DSS-induced colon tissues & $\begin{array}{l}\text { Down-regulate the increased phosphorylation } \\
\text { levels of NF-kBp65 }\end{array}$ & [71] \\
\hline & \multirow[t]{3}{*}{ Clove } & TNBS-induced colon tissue & Down-regulate the expressions of NF-kBp65 & {$[72]$} \\
\hline & & DSS-induced colon tissues & Reduce the expressions of p65-NF-kB & [73] \\
\hline & & RAW264.7 macrophages & Decrease the expressions of p65-NF-kB & [73] \\
\hline & Zanthoxylum bungeanum & DSS-induced colon tissue & Inhibit NF-KBp65 phosphorylation levels & {$[74]$} \\
\hline & Galangin & DSS-induced colon tissue & $\begin{array}{l}\text { Suppress protein expressions of p-NF-kB; } \\
\text { Decrease the accumulation of nuclear } \\
\text { NF-kBp65 }\end{array}$ & [75] \\
\hline
\end{tabular}


Table 1 (continued)

\begin{tabular}{|c|c|c|c|c|}
\hline Classifications & Chinese medicines & Models & Mechanisms & References \\
\hline \multirow{21}{*}{$\begin{array}{l}\text { Detoxificating and } \\
\text { purgative medicine }\end{array}$} & \multirow[t]{2}{*}{ Parthenolide } & DSS-induced colon tissue & Inhibit the phosphorylation of NF-kBp65 & {$[76]$} \\
\hline & & HCT116 cells & Block the activation of p65 & {$[77]$} \\
\hline & Arctigenin & DSS-induced colonic tissues & $\begin{array}{l}\text { Suppress phosphorylation of NF-kBp65 and p65 } \\
\text { translocation }\end{array}$ & {$[78]$} \\
\hline & $\begin{array}{l}\text { Andrographolide } \\
\text { derivative } A L-1\end{array}$ & TNBS-induced colon tissues & Aattenuate the expression levels of p-p65 & {$[79]$} \\
\hline & $\begin{array}{l}\text { Andrographolide } \\
\text { derivative } C X-10\end{array}$ & DSS-induced colonic tissue & Reduce the expressions of NF-kB p65 & {$[80]$} \\
\hline & Brusatol & DSS-induced colon tissue & Attenuate the expression of NF-kBp65 & {$[81]$} \\
\hline & Brucea javanica oil & DSS-induced colon tissues & $\begin{array}{l}\text { Suppress the NF-KB activation; Inhibit the } \\
\text { phosphorylation of NF-kBp65 }\end{array}$ & {$[82]$} \\
\hline & Oldenlandia diffusa & DSS-induced colon tissues & Reduce the activation of NF-kBp65 & {$[84]$} \\
\hline & Qing Dai & RAW264.7 cells & Abolish NF-kBp65 translocation to the nucleus & {$[86]$} \\
\hline & Indirubin & DSS-induced colon tissues & $\begin{array}{l}\text { Reverse DSS-mediated up-regulation of p-NF- } \\
\text { kBp65 }\end{array}$ & {$[87]$} \\
\hline & Dandelion & DSS-induced NCM460 cell & Decrease the phosphorylation of NF-kBp65 & {$[88]$} \\
\hline & Portulaca oleracea L. & DSS-induced colon tissues & Reduce the protein expressions of NF-kBp65 & {$[89]$} \\
\hline & \multirow{3}{*}{$\begin{array}{l}\text { Rhubarb-type } \\
\text { anthraquinones }\end{array}$} & RAW264.7 macrophages & Rhein reduce phosphor-NF-kBp65 levels & {$[91]$} \\
\hline & & HT-29 cells & Emodin block NF-kBp65 nuclear translocation & {$[92]$} \\
\hline & & DSS-induced colitis tissues & Chrysophanol reduce the activation of NF-kBp65 & {$[93]$} \\
\hline & Gallic acid & RAW264.7 macrophage & Decrease the expression of NF-kBp65 & {$[94]$} \\
\hline & Allicin & DSS-induced colonic mucosa & $\begin{array}{l}\text { Prevent the inhibition of inducing nuclear } \\
\text { translocation of NF-kBp65 }\end{array}$ & {$[95]$} \\
\hline & Cassia obtusifolia & DSS-induced colon tissues & Reduce the level of NF-kBp65 & {$[96]$} \\
\hline & Bergenin & RAW264.7 cells & $\begin{array}{l}\text { Suppress the nuclear translocation and } \\
\text { DNA-binding activity of NF-kBp65; Inhibit } \\
\text { the acetylation of NF-kBp65, increase the } \\
\text { association of NF-kBp65 and IkBa, and hinder } \\
\text { the nuclear translocation of NF-kBp65 }\end{array}$ & {$[97]$} \\
\hline & $\begin{array}{l}\text { Fagopyrum cymosum } \\
\text { (Trev.) Meisn }\end{array}$ & Raw264.7 cells & Inhibit NF-kBp65 nuclear translocation & {$[98]$} \\
\hline & Chlorogenic acid & DSS-induced colon mucosa & $\begin{array}{l}\text { Reduce the phosphorylation level of NF-kBp65 } \\
\text { protein }\end{array}$ & {$[99]$} \\
\hline \multirow{8}{*}{$\begin{array}{l}\text { Blood-activating } \\
\text { medicine }\end{array}$} & Paeonol & CW-2 cells & Reduce NF-kB transactivation & {$[99]$} \\
\hline & \multirow[t]{2}{*}{ Liriodendrin } & DSS-induced colon tissues & $\begin{array}{l}\text { Suppress the activation of NF-KB pathways; } \\
\text { Reduce in phosphorylation of NF-KB }\end{array}$ & {$[101]$} \\
\hline & & RAW264.7 macrophages & Reduce the phosphorylation of NF-kB & {$[101]$} \\
\hline & Shikonin & DSS-induced colon tissues & Reduce the expression of NF-kBp65 & {$[102]$} \\
\hline & Tetramethylpyrazine & OXZ-induced colitis mucosa & Reduce the rise in NF-kBp65 & {$[103]$} \\
\hline & Crocetin & TNBS-induced colonic mucosa & Down-regulate the NF-kB & {$[104]$} \\
\hline & Epicatechin & RAW264.7 cells & Inhibit the activation of NF-KB & {$[105]$} \\
\hline & Curcumin & Colonic mucosa & Modulate NF-kB activation & [110] \\
\hline
\end{tabular}


Table 1 (continued)

\begin{tabular}{|c|c|c|c|c|}
\hline Classifications & Chinese medicines & Models & Mechanisms & References \\
\hline \multirow[t]{3}{*}{ Qi-regulating medicine } & Norisoboldine & DSS-induced colon tissues & $\begin{array}{l}\text { Inhibit phosphorylation, nuclear translocation } \\
\text { and DNA-binding activity of NF-kBp65 }\end{array}$ & {$[113]$} \\
\hline & Citrus aurantium L. & TNBS-induced colon tissues & Inhibit the NF-kB pathway & {$[114]$} \\
\hline & & RAW264.7 cells & Inhibit the protein expressions of NF-KB & {$[114]$} \\
\hline \multirow[t]{11}{*}{ Tonifying medicine } & Eclipta Prostrata & HT-29 cells & Reduce the nuclear translocation of $\mathrm{NF}-\mathrm{kB}$ & {$[115]$} \\
\hline & $\begin{array}{l}\text { Astragalus } \\
\text { polysaccharide }\end{array}$ & DSS-induced colonic tissues & Reduce NF-kB DNA phosphorylation activity & {$[116]$} \\
\hline & Astragaloside IV & CCD-18Co cells & Inhibit the phosphorylation of NF-kBp65 & [117] \\
\hline & Licochalcone A & DSS-induced colonic tissues & Reverse the increased expression of p65 NF-kB & {$[118]$} \\
\hline & $\begin{array}{l}\text { Diammonium } \\
\text { glycyrrhizinate }\end{array}$ & AA-induced colonic tissues & $\begin{array}{l}\text { Suppress the positive percentage and density of } \\
\text { NF-kBp65 }\end{array}$ & {$[119]$} \\
\hline & Vanillic acid & DSS-induced colon tissues & $\begin{array}{l}\text { Suppress the activation of transcription } \\
\text { NF-kBp65 }\end{array}$ & {$[120]$} \\
\hline & Paeoniflorin & TNBS-induced colon tissues & Inhibit the expressions of p-NF-kB & {$[121]$} \\
\hline & $\begin{array}{l}\text { The fruit of Ziziphus } \\
\text { jujuba Mill. }\end{array}$ & $\begin{array}{l}\text { AOM/DSS-induced colon } \\
\text { tissue }\end{array}$ & Attenuate the expression of proteins in the NF-KB & {$[122]$} \\
\hline & Oligonol & DSS-induced colon tissue & Decrease nuclear translocation of NF-kBp65 & {$[123]$} \\
\hline & Lentinus edodes $\beta$-glucans & RAW264.7 cells & Inhibit NF-kB activation & {$[124]$} \\
\hline & Mango extract & CCD-18Co cells & Reduce expression of NF-kB and pNF-kB protein & {$[125]$} \\
\hline \multirow[t]{5}{*}{ Astringent medicine } & Muscovite & $\begin{array}{l}\text { lodoacetamide-induced colitis } \\
\text { tissues }\end{array}$ & $\begin{array}{l}\text { Decrease the activity of NF-kBp65 and reduce } \\
\text { the p65 transferred into the nucleus }\end{array}$ & {$[126]$} \\
\hline & Shan Zhu Yu & $\begin{array}{l}\text { Human umbilical vein } \\
\text { endothelial cells (HUVECs) }\end{array}$ & Attenuate NF-KB expression & {$[127]$} \\
\hline & & Macrophages & Inhibit NF-KB activation & {$[129]$} \\
\hline & Rubus coreanus & RAW264.7 macrophages & Attenuate the nuclear translocations of NF-kBp65 & {$[130]$} \\
\hline & & RAW 264.7 cells & Reduce NF-kB activity & {$[131]$} \\
\hline $\begin{array}{l}\text { Tonifying Qi and } \\
\text { activating blood } \\
\text { category }\end{array}$ & Tou Nong San & TNBS-induced colon tissue & Reduce the activation of the NF-kBp65 & {$[134]$} \\
\hline \multirow{15}{*}{$\begin{array}{l}\text { Heat-clearing and } \\
\text { drying dampness } \\
\text { category }\end{array}$} & Shaoyao Decoction & $\begin{array}{l}\text { AOM/DSS-induced colonic } \\
\text { tissues }\end{array}$ & Suppress NF-KB activation & {$[135]$} \\
\hline & Qingchang Huashi recipe & HT-29 cells & Reduce the activation of NF-kB & {$[137]$} \\
\hline & Gegenqinlian Decoction & TNBS-induced colon tissue & $\begin{array}{l}\text { Inhibit the activation and translocation of } \\
\text { NF-kBp65 }\end{array}$ & {$[138]$} \\
\hline & & DSS-induced colonic tissues & Decrease the P-NF-kBp65 & {$[139]$} \\
\hline & & RAW 264.7 cells & Down-regulate the expression of P-NF-kBp65 & {$[139]$} \\
\hline & $\begin{array}{l}\text { Jianpi Qingchang } \\
\text { decoction }\end{array}$ & DSS-induced colon tissue & Inhibit the activation of the NF-KB & {$[140]$} \\
\hline & $\begin{array}{l}\text { Modified pulsatilla } \\
\text { decoction }\end{array}$ & OXZ-induced colon tissues & Suppress the activation of the NF-kB & {$[142]$} \\
\hline & Qing Hua Chang Yin & DSS-induced colon tissue & $\begin{array}{l}\text { Inhibit the expression of the nuclear } \\
\text { translocation of NF-KB }\end{array}$ & {$[143]$} \\
\hline & QingBai decoction & DSS-induced colon tissue & Decrease the protein level of P-NF-kBp65 & {$[145]$} \\
\hline & Chang-An-Shuan & TNBS-induced colonic tissues & Down-regulate the expression levels of NF-kBp65 & {$[146]$} \\
\hline & Baishaoqiwu & TNBS-induced colon tissues & Inhibit expression of the NF-kBp65 genes & {$[147]$} \\
\hline & Xie-xin decoction & TNBS-induced colon tissues & Decrease expression of NF-kBp65 & {$[148]$} \\
\hline & $\begin{array}{l}\text { Compound sophorae } \\
\text { decoction }\end{array}$ & DSS-induced colonic tissues & Reduce the level of phospho-NF-kBp65 & {$[149]$} \\
\hline & $\begin{array}{l}\text { Huangkui Lianchang } \\
\text { decoction }\end{array}$ & DSS-induced Colon Tissue & Decrease the NF-B levels & {$[150]$} \\
\hline & Bawei Xilei powder & UC patients & Decrease the expression of NF-kBp65 & {$[151]$} \\
\hline
\end{tabular}


Table 1 (continued)

\begin{tabular}{|c|c|c|c|c|}
\hline Classifications & Chinese medicines & Models & Mechanisms & References \\
\hline \multirow{2}{*}{$\begin{array}{l}\text { Harmonizing cold and } \\
\text { hot category }\end{array}$} & Ban-xia-xie-xin decoction & DSS-induced colorectums & Inhibition of NF-KBp65 activation & [152] \\
\hline & Wu-mei-wan & DNCB-induced colonic tissue & Inhibit the NF-kBp65 activity & [153] \\
\hline \multirow{3}{*}{$\begin{array}{l}\text { Warming yang and } \\
\text { drying dampness } \\
\text { category }\end{array}$} & $\begin{array}{l}\text { Modified ZenWu } \\
\text { decoction }\end{array}$ & DSS-induced colonic tissues & $\begin{array}{l}\text { Attenuate the activation of NF-KB and suppress } \\
\text { the expression of NF-kBp65 }\end{array}$ & [154] \\
\hline & Ping weisan & DSS-induced colon tissues & Reduce phosphorylation of NF-kBp65 & [155] \\
\hline & & RAW264.7cells & Reduce phosphorylation of NF-KBp65 & [155] \\
\hline Astringent category & $\begin{array}{l}\text { Zhenrenyangzang } \\
\text { decoction }\end{array}$ & TNBS-induced colon tissues & Reduce NF-kB mRNA expression & [156] \\
\hline
\end{tabular}

medicine and formulae, and detoxificating and purgative medicine exert distinguished actions, which embodies enhancing the activity of $\mathrm{I} k \mathrm{~B} \alpha$ to decrease phosphorylated $\mathrm{p} 65$ or inhibiting the degradation of $\mathrm{I} \kappa \mathrm{B} \alpha$ binding to p65. Apart from affecting $\mathrm{I} \kappa \mathrm{B} \alpha$, some Chinese medicines and their active compounds are able to regulate the activity of NF- $\mathrm{KB}$ by affecting AKT, TLR4/ MyD88, PPAR $\gamma /$ SIRT1, p-IKK $\beta /$ IKK $\beta$, p38MAPK/ERK/ JNK, TLR5/MyD88, p-STAT3. As shown in Tables 1 and 2, from the analysis on the frequency of Chinese medicines with different therapeutic function for treating $\mathrm{UC}$, it suggests that the screening of Chinese medicines for UC treatment might be focused on the candidate agents with dampness-drying and detoxificating effects in future.

Furthermore, cell-specific role of NF- $\mathrm{B}$ has been demonstrated to involve in the pathogenesis of IBD [158]. It suggests the enhancement of NF-кBp65 exists in macrophages and epithelial cells isolated from inflamed gut specimens from IBD patients [159]. Except for macrophages and epithelial cells, lamina propria fibroblasts also plays a NF- $\mathrm{B}$ mediated pro-inflammatory role in IBD [160]. Increased NF$\mathrm{kB}$ expression in mucosal macrophages causes the productions of pro-inflammatory cytokines such as TNF- $\alpha$, IL-1 and IL- 6 directly resulting in the mucosal tissue damage, and in colonic epithelial cells it is related to an increased expression of intercellular adhesion molecule-1 that contributes to the recruitment of neutrophil granulocytes to the site of inflammation [161]. NF-kB-induced cytokines further stimulate, activate and differentiate lamina propria immune cells, which aggravates the perpetuation of mucosal inflammation. In this review, we find that $55 \%$ of Chinese medicines having the abilities of regulating NF- $\mathrm{KB}$ expression in macrophages (e.g., SM934, artesunate, aesculin, gallic acid and epicatechin) repress the nucleus translocation and phosphorylation of NF- $\mathrm{kBp} 65$, inhibit the protein expressions and phosphorylation of NF- $\mathrm{kB}$, whereas $45 \%$ (e.g., berberine, Total flavonoids of $H$. diffusa
Willd, F. cymosum (Trev.) Meisn and osthole) block the phosphorylation of $I \kappa B$, reduce the degradation of $\mathrm{I} \kappa \mathrm{B} \alpha$ protein. It suggests that Chinese medicines with detoxificating and purgative function have the most obvious inhibited effects of NF- $\mathrm{B}$ pathway on macrophages. Additionally, other active compounds or extracts of Chinese medicines, such as Chinese herb pair Paeoniae Radix Alba and Atractylodis Macrocephalae Rhizoma, Corni Fructus aqueous extract and cornuside, Siegesbeckia pubescens Makino, which can inactivate NF-kB pathway in macrophage, perhaps became candidate drugs for treating UC in future [162-164].

Apart from NF-kB, Nrf2 is also a key transcription factor that protects cells and tissues from inflammation, and it has been found to be implicated in the pathogenesis of UC [165]. Study reports that when Nrf2 expression rises in colon tissue, the inflammatory injury significantly attenuates, demonstrating that $\mathrm{Nrf} 2$ has a protective effect on the colon [166]. Meanwhile, scholars find that there are multiple associations between Nrf2 and NF- $\mathrm{KB}$ [167]. For example, the absence of Nrf2 leads to oxidative stress activation, which contributes to increasing NF- $\mathrm{kB}-$ mediated cytokines expression. In present study, we find some active compounds of Chinese medicines and formulae, e.g., galangin, oligonol, bai-xia-xie-xin decoction, can either increase the nuclear translocation of $\mathrm{Nrf} 2$ or inhibit NF-kB pathway, suggesting the advantages of Chinese medicines' multi-targets and comprehensive regulated abilities for UC treatment.

Additionally, numerous literature have reported Chinese herbal drugs administered by both, oral intake and retention enema, exert significant therapeutic actions in the treatment of IBD, and in order to understand the detailed mechanisms of Chinese medicines therapy on $\mathrm{UC}$, the application of experimental rodent models is essential $[168,169]$. In this review, we summarized the researches mainly from animal or human cell models, e.g. DSS-induced model is common pathological UC model. It suggests that the establishment of chronic colitis and the development of colorectal dysplasias and cancers 


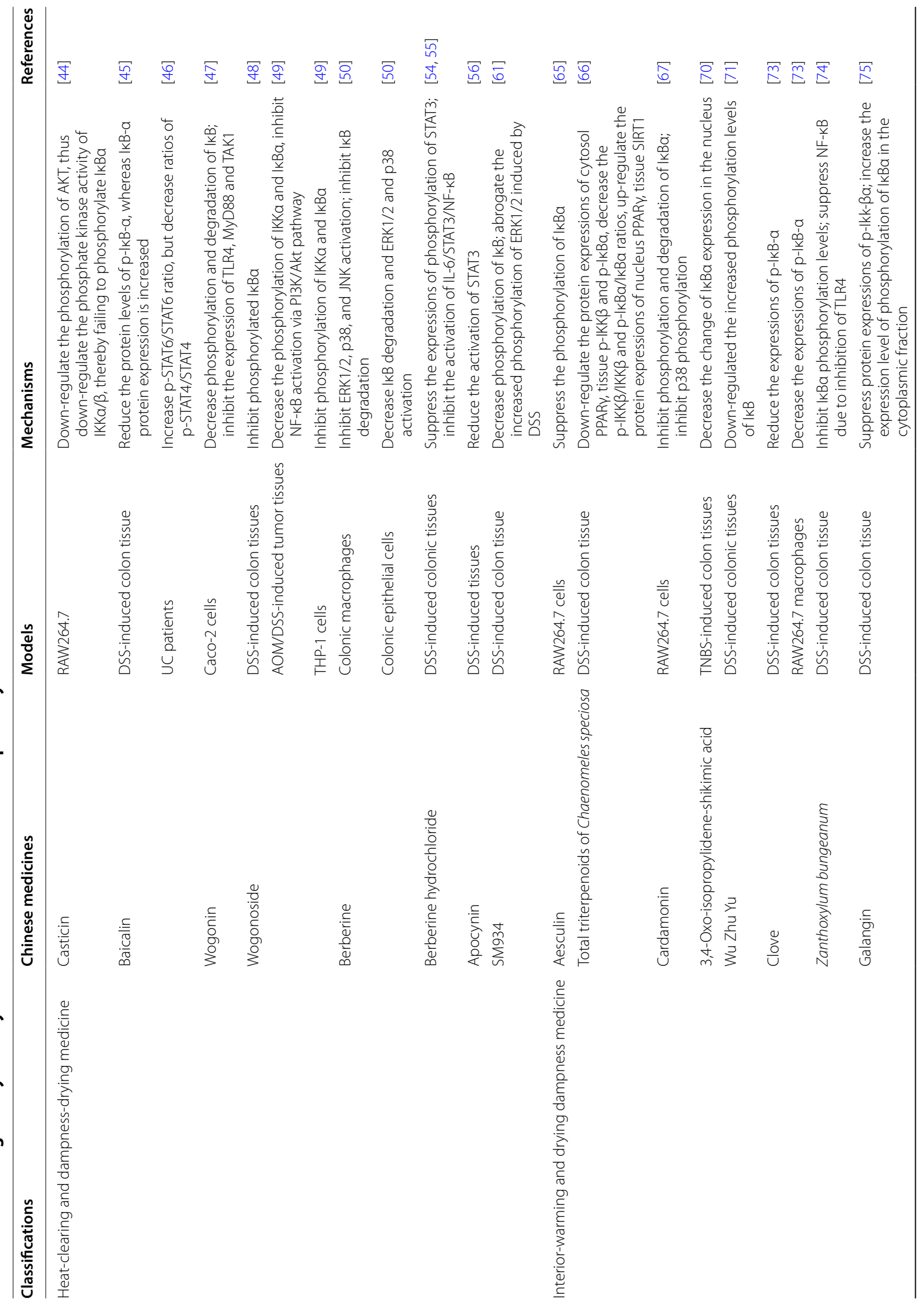




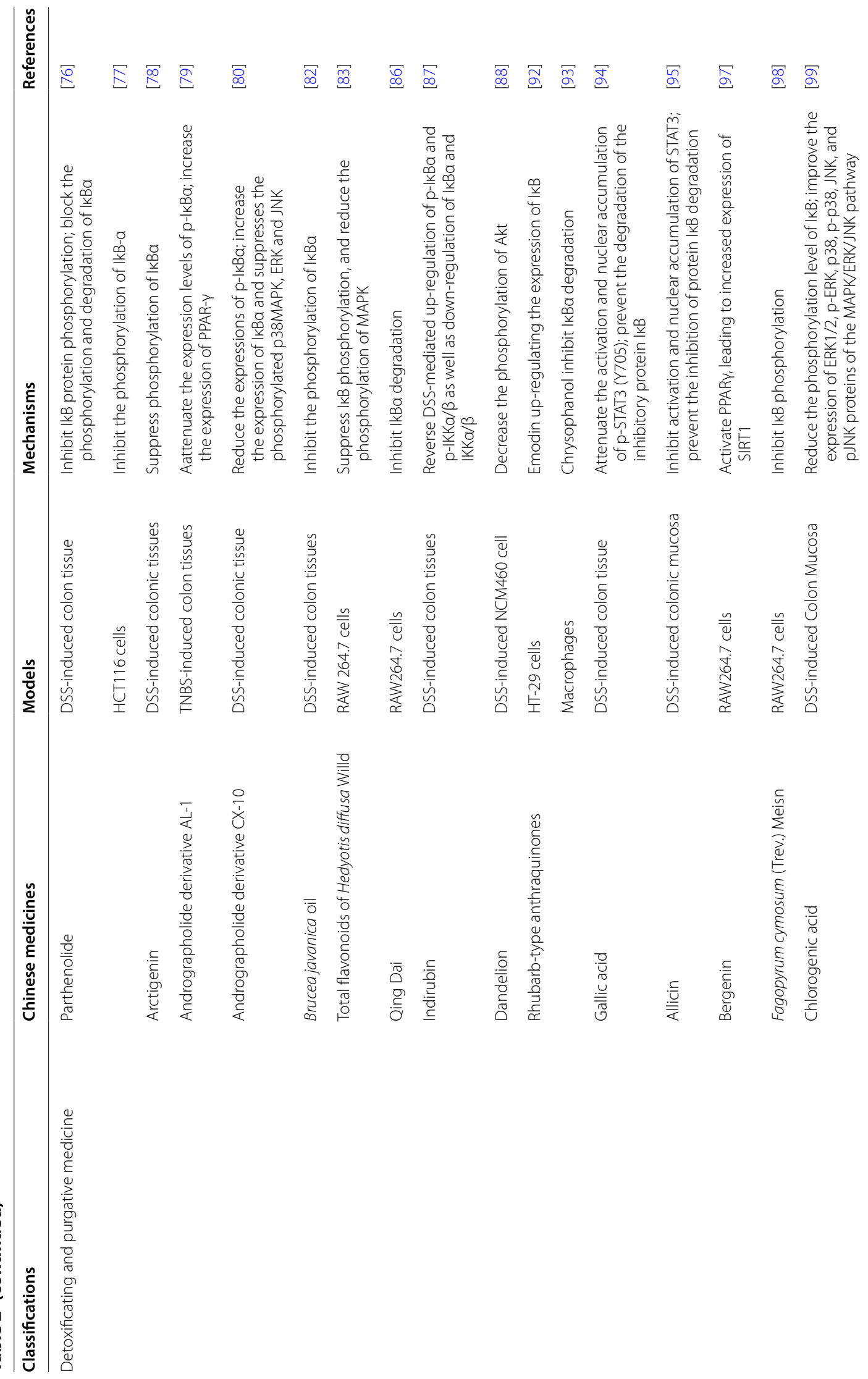




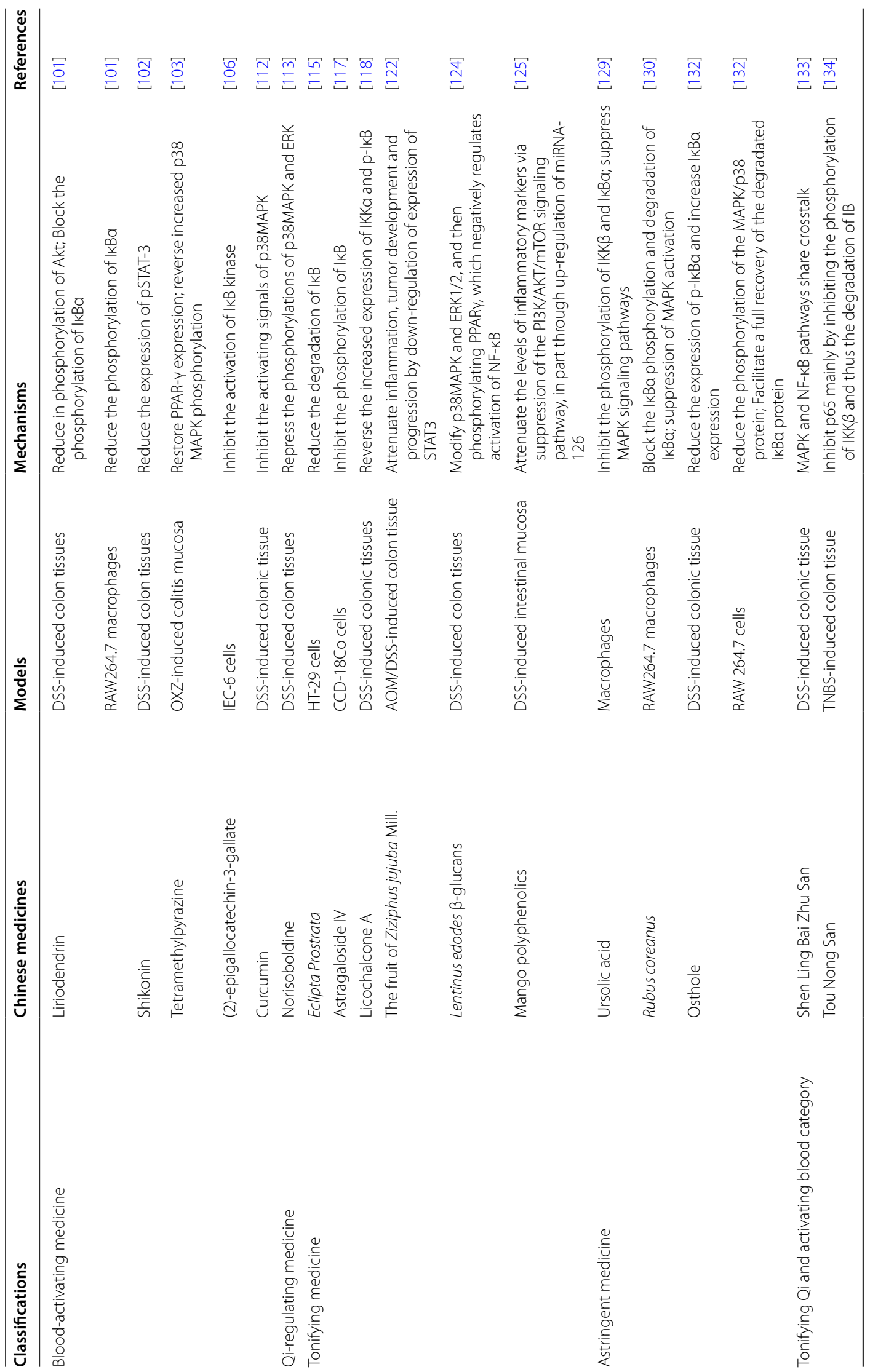




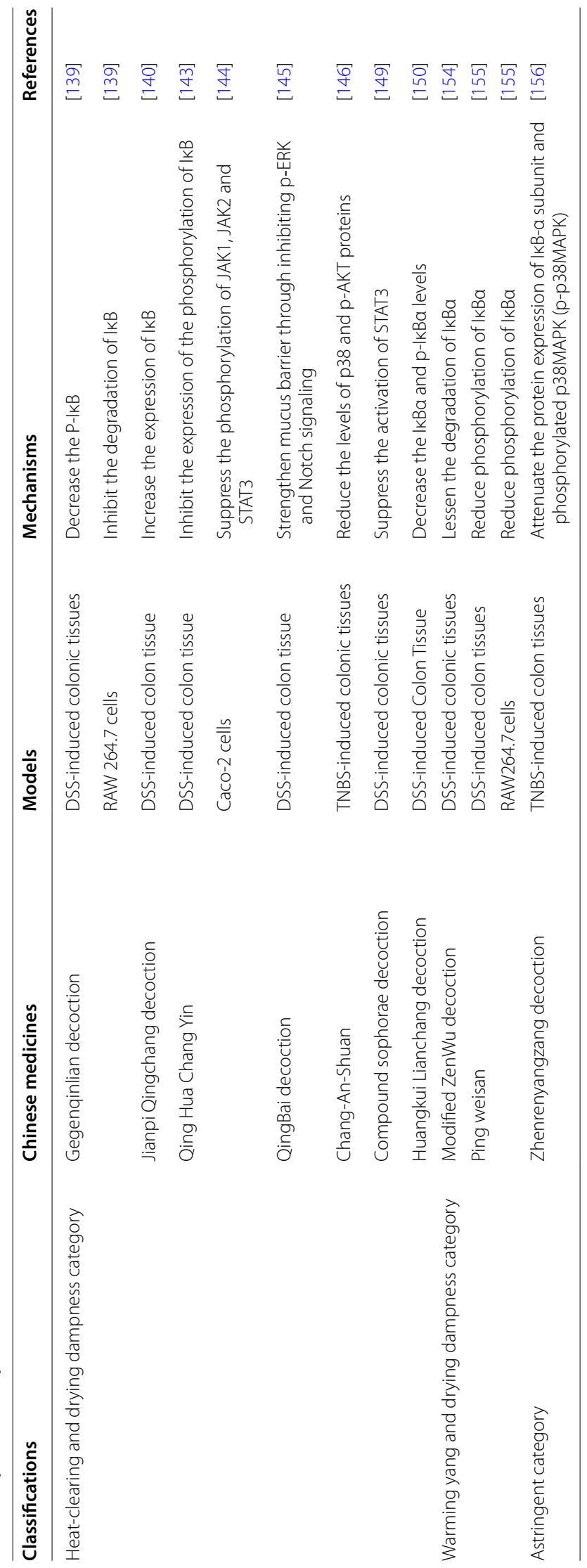




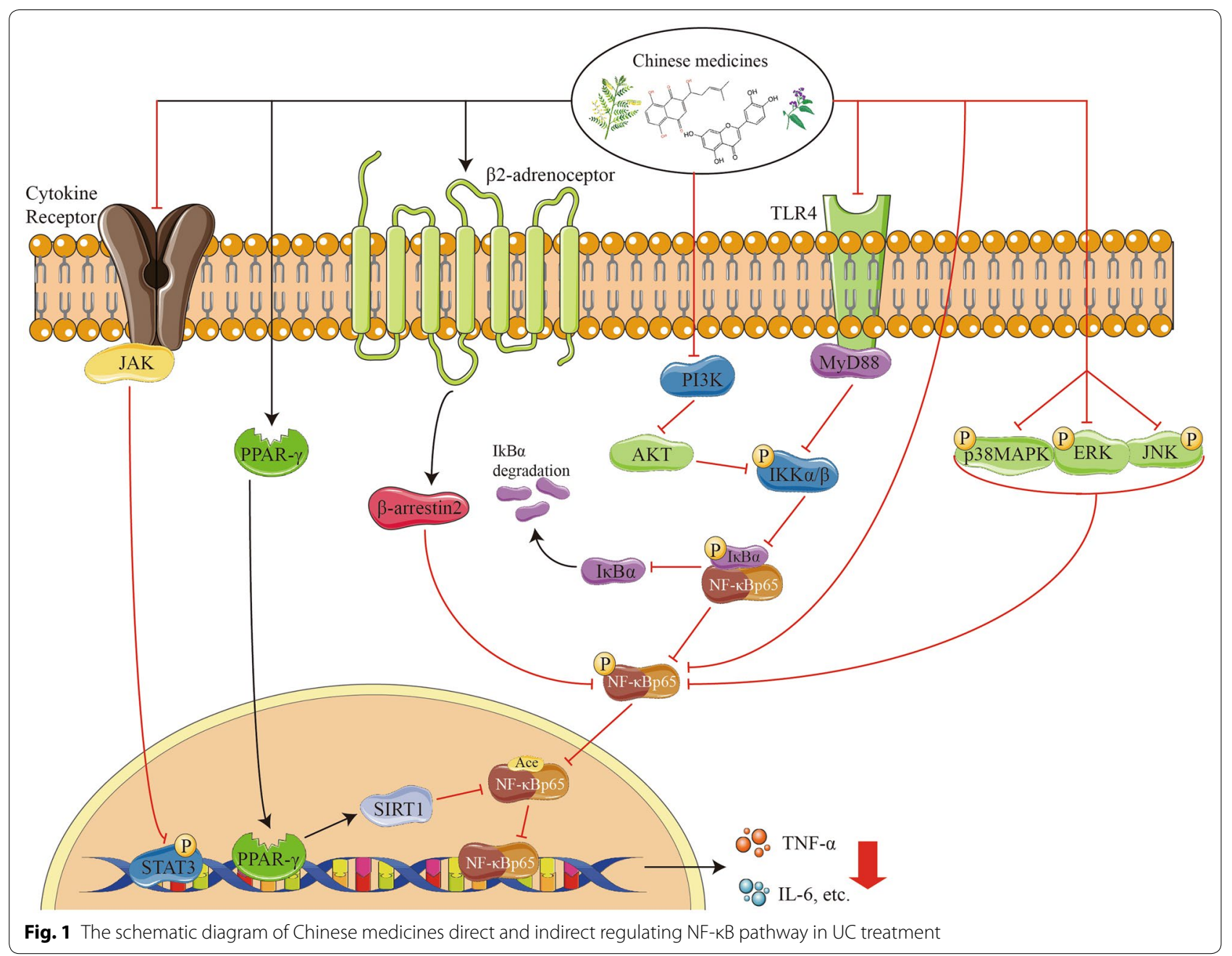

with pathological features by DSS-induced rodent models resemble those of human colitis, suggesting that DSSinduced colitis may be an appropriate model to evaluate the clinical efficacy of candidate agents for UC [170, 171]. Therefore, we can infer some characteristics of Chinese medicine from analyzing UC animal models based on traditional Chinese herbal therapeutic functions. In addition, the development of novel deliver Chinese medicines for the treatment of IBD will more greatly enhance the therapeutic effects and safety of Chinese medicines, as well as reduce the cost of treatment [172].

In summary, evidences show that Chinese medicines exert a vital action on the treatment of $\mathrm{UC}$ by direct and indirect regulation of NF- $\mathrm{KB}$ pathway (Fig. 1), and the category of dampness-drying and detoxificating medicine accounts for the main status. This review not only further validates the scientificity of Chinese medicine on the pathogenesis of UC by categorized therapeutic agents and formulae according to their traditional functions, but also suggests the characteristics of comprehensive modulated abilities of Chinese medicines. Moreover, by careful analysis on cell-specific role of NF- $\mathrm{KB}$ in UC, novel Chinese medicines precisely modulate NF-kB becomes possible. Simultaneously, this review contributes to the choices of Chinese medicine category and provides curative potential of Chinese medicines for clinical UC treatment. Of course, more systematic and detailed pharmacological studies on Chinese medicines need to be fulfilled and provide more evidences to validate Chinese medicines' efficacy and safety in the future.

\section{Abbreviations}

COX2: Cyclooxygenase-2; DSS: Dextran sulfate sodium; ERK: Extracellular regulated protein kinases; IFN- $\gamma$ : Interferon gamma; IKK $\beta$ : Inhibitor of nuclear factor KB kinase subunit $\beta$; IL: Interleukin; iNOS: Inducible nitric oxide synthase; JNK: c-Jun N-terminal kinase; LPS: Lipopolysaccharide; MAPK: Mitogen-activated protein kinase; MLC: Myosin light chain; MyD88: Myeloid differentiation factor 88; NO: Nitric oxide; OXZ: Oxazolone; PGE2: Prostaglandin E2; PPAR- $\gamma$ : Peroxisome proliferator-activated receptor gamma; ROS: Reactive oxygen species; STAT3: Signal transducer and activator of transcription 3; TLR4: 
Toll like receptor 4; TNBS: Trinitrobenzene sulfonic acid; TNF: Tumor necrosis factor; UC: Ulcerative colitis.

\section{Acknowledgements}

Not applicable.

\section{Authors' contributions}

YHZ conceived the review and PDL wrote the manuscript. Both authors read and approved the final manuscript.

\section{Funding}

This work was funded by University of Macau (No. SRG2019-00164-ICMS).

\section{Availability of data and materials}

Not applicable.

\section{Ethics approval and consent to participate}

Not applicable.

\section{Consent for publication}

All authors have provided consent for publication in the Journal of Chinese Medicine.

\section{Competing interests}

The authors declare that they have no competing interests.

\section{Author details}

1 School of Pharmaceutical Sciences, Guangzhou University of Chinese Medicine, Guangzhou, China. ${ }^{2}$ State Key Laboratory of Quality Research in Chinese Medicine, Institute of Chinese Medical Sciences, University of Macau, Taipa 999078, Macao, Special Administrative Region of China.

\section{Received: 26 November 2019 Accepted: 30 January 2020}

Published online: 10 February 2020

\section{References}

1. Ng SC, Shi HY, Hamidi N, Underwood FE, Tang W, Benchimol El, Panaccione R, Ghosh S, Wu JCY, Chan FKL, Sung JJY, Kaplan GG. Worldwide incidence and prevalence of inflammatory bowel disease in the 21 st century: a systematic review of population-based studies. Lancet. 2018;390:2769-78.

2. Yang SK, Yun S, Kim JH, Park JY, Kim HY, Kim YH, Chang DK, Kim JS, Song IS, Park JB, Park ER, Kim KJ, Moon G, Yang SH. Epidemiology of inflammatory bowel disease in the Songpa-Kangdong district, Seoul, Korea, 1986-2005: a KASID study. Inflamm Bowel Dis. 2008;14:542-9.

3. Jung YS, Han M, Kim WH, Park S, Cheon JH. Incidence and clinical outcomes of inflammatory bowel disease in South Korea, 2011-2014: a nationwide population-based study. Dig Dis Sci. 2017;62:2102-12.

4. Zeng Z, Zhu Z, Yang Y, Ruan W, Peng X, Su Y, Peng L, Chen J, Yin Q, Zhao C, Zhou H, Yuan S, Hao Y, Qian J, Ng SC, Chen M, Hu P. Incidence and clinical characteristics of inflammatory bowel disease in a developed region of Guangdong Province, China: a prospective population-based study. J Gastroenterol Hepatol. 2013;28:1148-53.

5. Yang H, Li Y, Wu W, Sun Q, Zhang Y, Zhao W, Lv H, Xia Q, Hu P, Li H, Qian J. The incidence of inflammatory bowel disease in Northern China: a prospective population-based study. PLoS ONE. 2014;9:e101296.

6. Wang Y, Ouyang Q. Ulcerative colitis in China: retrospective analysis of 3100 hospitalized patients. J Gastroenterol Hepatol. 2007;22:1450-5.

7. Panaccione R, Ghosh S, Middleton S, Márquez JR, Scott BB, Flint $L$, van Hoogstraten HJ, Chen AC, Zheng H, Danese S, Rutgeerts P. Combination therapy with infliximab and azathioprine is superior to monotherapy with either agent in ulcerative colitis. Gastroenterology. 2014;146(392-400):e3.

8. Veloso FT. Skin complications associated with inflammatory bowel disease. Aliment Pharmacol Ther. 2004;20:50-3.

9. Pellicer Z, Santiago JM, Rodriguez A, Alonso V, Antón R, Bosca MM. Management of cutaneous disorders related to inflammatory bowel disease. Ann Gastroenterol. 2012:25:21-6.
10. Vavricka SR, Schoepfer AM, Scharl M, Lakatos P, Navarini AA, Rogler G. Extraintestinal manifestations of inflammatory bowel disease. Inflamm Bowel Dis. 2015;21:1982-92.

11. Calvo P, Pablo L. Managing IBD outside the gut: ocular manifestations. Dig Dis. 2013;31:229-32.

12. Manganelli C, Turco S, Balestrazzi E. Ophthalmological aspects of IBD. Eur Rev Med Pharmacol Sci. 2009:13(Suppl 1):11-3.

13. Katsanos A, Asproudis I, Katsanos KH, Dastiridou Al, Aspiotis M, Tsianos EV. Orbital and optic nerve complications of inflammatory bowel disease. J Crohns Colitis. 2013;7:683-93.

14. Gondim FA, Brannagan TH, Sander HW, Chin RL, Latov N. Peripheral neuropathy in patients with inflammatory bowel disease. Brain. 2005; 128:867-79.

15. Vennera MD, Picado C. Pulmonary manifestations of inflammatory bowel disease. Arch Bronconeumol. 2005;41:93-8.

16. Harbord M, Eliakim R, Bettenworth D, Karmiris K, Katsanos K, Kopylov U, Kucharzik T, et al. Corrigendum: third European evidence-based consensus on diagnosis and management of ulcerative colitis. Part 2: current management. J Crohns Colitis. 2017;11:1512.

17. Rioux JD. International inflammatory bowel disease genetics consortium identifies $>50$ genetic risk factors for ulcerative colitis. Gastroenterology. 2010;139:e19.

18. Oh SJ, Lee CK, Kim YW, Jeong SJ, Park YM, Oh CH, Kim JW, Kim HJ. True cytomegalovirus colitis is a poor prognostic indicator in patients with ulcerative colitis flares: the 10-year experience of an academic referral inflammatory bowel disease center. Scand J Gastroenterol. 2019;54:976-83.

19. Duranti S, Gaiani F, Mancabelli L, Milani C, Grandi A, Bolchi A, Santoni A, et al. Elucidating the gut microbiome of ulcerative colitis: bifidobacteria as novel microbial biomarkers. FEMS Microbiol Ecol. 2016;92:fiw191.

20. Peterson CT, Sharma V, Elmén L, Peterson SN. Immune homeostasis, dysbiosis and therapeutic modulation of the gut microbiota. Clin Exp Immunol. 2015;179:363-77.

21. Uchiyama K, Nakamura M, Odahara S, Koido S, Katahira K, Shiraishi H, Ohkusa T, Fujise K, Tajiri H. N-3 polyunsaturated fatty acid diet therapy for patients with inflammatory bowel disease. Inflamm Bowel Dis. 2010;16:1696-707.

22. Ioannidis O, Varnalidis I, Paraskevas G, Botsios D. Nutritional modulation of the inflammatory bowel response. Digestion. 2011;84:89-101.

23. Magro F, Gionchetti P, Eliakim R, Ardizzone S, Armuzzi A, Barreiro-de Acosta M, Burisch J, et al. Third European evidence-based consensus on diagnosis and management of ulcerative colitis. Part 1: definitions, diagnosis, extra-intestinal manifestations, pregnancy, cancer surveillance, surgery, and ileo-anal pouch disorders. J Crohns Colitis. 2017;11:649-70.

24. Ford AC, Khan KJ, Achkar JP, Moayyedi P. Efficacy of oral vs. topical, or combined oral and topical 5-aminosalicylates, in ulcerative colitis: systematic review and meta-analysis. Am J Gastroenterol. 2012;107:167-76

25. Sandborn WJ, Bosworth B, Zakko S, Gordon GL, Clemmons DR, Golden $\mathrm{PL}$, Rolleri $\mathrm{RL}$, et al. Budesonide foam induces remission in patients with mild to moderate ulcerative proctitis and ulcerative proctosigmoiditis. Gastroenterology. 2015;148(740-750):e2

26. Nielsen $\mathrm{OH}$, Bjerrum JT, Herfarth $\mathrm{H}$, Rogler $\mathrm{G}$. Recent advances using immunomodulators for inflammatory bowel disease. J Clin Pharmacol. 2013;53:575-88.

27. Colombel JF, Keir ME, Scherl A, Zhao R, de Hertogh G, Faubion WA, Lu TT. Discrepancies between patient-reported outcomes, and endoscopic and histological appearance in UC. Gut. 2017;66:2063-8.

28. Chen G, Yang Y, Hu C, Cheng X, Xu Y, Cai X, Wang M, Yang CS, Cao P. Protective effects of Huangqin Decoction against ulcerative colitis and associated cancer in mice. Oncotarget. 2016;7:61643-55.

29. Chen P, Zhou X, Zhang L, Shan M, Bao B, Cao Y, Kang A, Ding A. Antiinflammatory effects of Huangqin tang extract in mice on ulcerative colitis. J Ethnopharmacol. 2015;162:207-14.

30. Kawashima K, Nomura A, Makino T, Saito K, Kano Y. Pharmacological properties of traditional medicine. (XXIX): effect of hange-shashin-to and the combinations of its herbal constituents on rat experimental colitis. Biol Pharm Bull. 2004;27:1599-603.

31. Zhao L, Wu H, Zhao A, Lu H, Sun W, Ma C, Yang Y, Xin X, Zou H, Qiu M, Jia W. The in vivo and in vitro study of polysaccharides from a two-herb 
formula on ulcerative colitis and potential mechanism of action. J Ethnopharmacol. 2014;153:151-9.

32. Moher D, Shamseer L, Clarke M, Ghersi D, Liberati A, Petticrew M, Shekelle P, Stewart LA, et al. Preferred reporting items for systematic review and meta-analysis protocols (PRISMA-P) 2015 statement. Syst Rev. 2015;4:1.

33. Jiang XL, Cui HF. An analysis of 10218 ulcerative colitis cases in China. World J Gastroenterol. 2002;8:158-61.

34. Dai YC, Zhang YL, Wang LJ, Guo Q, Yang K, Ye RH, Tang ZP. Clinical presentation and treatment strategies for ulcerative colitis: a retrospective study of 247 inpatients. Chin J Integr Med. 2016;22:811-6.

35. Liu B, Piao X, Guo L, Wang G, Sun W, Gao L, Zheng X, Fang Y. A new Chinese medicine intestine formula greatly improves the effect of aminosalicylate on ulcerative colitis. Evid Based Complement Alternat Med. 2017;2017:7323129.

36. Lang A, Salomon N, Wu JC, Kopylov U, Lahat A, Har-Noy O, Ching JY, et al. Curcumin in combination with mesalamine induces remission in patients with mild-to-moderate ulcerative colitis in a randomized controlled trial. Clin Gastroenterol Hepatol. 2015;13(1444-9):e1.

37. Hegazy SK, El-Bedewy MM. Effect of probiotics on pro-inflammatory cytokines and NF-KB activation in ulcerative colitis. World J Gastroenterol. 2010;16:4145-51.

38. Sakthivel KM, Guruvayoorappan C. Protective effect of Acacia ferruginea against ulcerative colitis via modulating inflammatory mediators, cytokine profile and NF-KB signal transduction pathways. J Environ Pathol Toxicol Oncol. 2014;33:83-98.

39. Wang X, Liu Y, Dong H, Wu L, Feng X, Zhou Z, Zhao C, Liu H, Wu H. Herbpartitioned moxibustion regulates the TLR2/NF-KB signaling pathway in a rat model of ulcerative colitis. Evid Based Complement Alternat Med. 2015;2015:949065

40. Woodford-Richens K, Bevan S, Churchman M, Dowling B, Jones D, Norbury CG, Hodgson SV, et al. Analysis of genetic and phenotypic heterogeneity in juvenile polyposis. Gut. 2000;46:656-60.

41. Yu ZH, Huang F, Xu N, Zhao DM, Hu FA, Liu J, Liu HF. Expression of Toll-like receptor 4, CD14, and NF-KB in Chinese patients with ulcerative colitis. J Immunoassay Immunochem. 2011;32:47-56.

42. Li Z, Zhang DK, Yi WQ, Ouyang Q, Chen YQ, Gan HT. NF-KB p65 antisense oligonucleotides may serve as a novel molecular approach for the treatment of patients with ulcerative colitis. Arch Med Res. 2008;39:729-34.

43. Chen ZS. Progress of integrative medical research on ulcerative colitis. Zhongguo Zhong Xi Yi Jie He Za Zhi. 2010;30:104-9.

44. Ma J, Yin G, Lu Z, Xie P, Zhou H, Liu J, Yu L. Casticin prevents DSS induced ulcerative colitis in mice through inhibitions of NF-kB pathway and ROS signaling. Phytother Res. 2018;32:1770-83.

45. Zhang CL, Zhang S, He WX, Lu JL, Xu YJ, Yang JY, Liu D. Baicalin may alleviate inflammatory infiltration in dextran sodium sulfate-induced chronic ulcerative colitis via inhibiting IL-33 expression. Life Sci. 2017;186:125-32.

46. Yu FY, Huang SG, Zhang HY, Ye H, Chi HG, Zou Y, Lv RX, Zheng XB. Effects of baicalin in CD4+ CD29+T cell subsets of ulcerative colitis patients. World J Gastroenterol. 2014;20:15299-309.

47. Wang W, Xia T, Yu X. Wogonin suppresses inflammatory response and maintains intestinal barrier function via TLR4-MyD88-TAK1-mediated NF-KB pathway in vitro. Inflamm Res. 2015;64:423-31.

48. Sun Y, Zhao Y, Yao J, Zhao L, Wu Z, Wang Y, Pan D, Miao H, Guo Q, Lu N. Wogonoside protects against dextran sulfate sodiuminduced experimental colitis in mice by inhibiting NF-KB and NLRP3 inflammasome activation. Biochem Pharmacol. 2015;94:142-54.

49. Sun Y, Zhao Y, Wang X, Zhao L, Li W, Ding Y, Kong L, Guo Q, Lu N. Wogonoside prevents colitis-associated colorectal carcinogenesis and colon cancer progression in inflammation-related microenvironment via inhibiting NF-KB activation through PI3K/Akt pathway. Oncotarget. 2016;7:34300-15.

50. Yan F, Wang L, Shi Y, Cao H, Liu L, Washington MK, Chaturvedi R, et al. Berberine promotes recovery of colitis and inhibits inflammatory responses in colonic macrophages and epithelial cells in DSS-treated mice. Am J Physiol Gastrointest Liver Physiol. 2012;302:G504-14.

51. Zhang LC, Wang Y, Tong LC, Sun S, Liu WY, Zhang S, Wang RM, Wang ZB, Li L. Berberine alleviates dextran sodium sulfate-induced colitis by improving intestinal barrier function and reducing inflammation and oxidative stress. Exp Ther Med. 2017;13:3374-82.

52. Cao M, Wang P, Sun C, He W, Wang F. Amelioration of IFN- $\gamma$ and TNFa-induced intestinal epithelial barrier dysfunction by berberine via suppression of MLCK-MLC phosphorylation signaling pathway. PLOS ONE. 2013;8:e61944.

53. Zhang H, Song G, Zhang Z, Song H, Tang X, Deng A, Wang W, Wu L, Qin $H$. Colitis is effectively ameliorated by $( \pm)$-8-acetonyl-dihydrocoptisine via the XBP1-NF-KB pathway. Front Pharmacol. 2017:8:619.

54. Zhu L, Gu P, Shen H. Protective effects of berberine hydrochloride on DSS-induced ulcerative colitis in rats. Int Immunopharmacol. 2019:68:242-51.

55. Meng FC, Wu ZF, Yin ZQ, Lin LG, Wang R, Zhang QW. Coptidis rhizoma and its main bioactive components: recent advances in chemical investigation, quality evaluation and pharmacological activity. Chin Med. 2018;13:13.

56. Marín M, Giner RM, Ríos JL, Recio Mdel C. Protective effect of apocynin in a mouse model of chemically-induced colitis. Planta Med. 2013;79:1392-400.

57. Zhong ZD, Xiong YA, Yang L. Effect of Matrine on the expression of cytokines and free radicals of intestinal mucosa in rats with TNBSinduced ulcerative colitis. Chin Med Biotechnol. 2011;4:251-4.

58. Tang $Q$, Fan H, Shou Z, Liu X. Study on protective mechanism of kushenin injection on colonic mucosa of experimental colitis rats. Zhongguo Zhong Yao Za Zhi. 2012;37:1814-7.

59. Fan $H$, Liao $Y$, Tang $Q$, Chen $X Y$, Zhang LJ, Liu XX, Zhong M. Role of $\beta 2$-adrenoceptor- $\beta$-arrestin2-nuclear factor-kB signal transduction pathway and intervention effects of oxymatrine in ulcerative colitis. Chin J Integr Med. 2012;18:514-21.

60. Chen YL, Zhang YL, Dai YC, Tang ZP. Systems pharmacology approach reveals the antiinflammatory effects of Ampelopsis grossedentata on dextran sodium sulfate-induced colitis. World J Gastroenterol. 2018;24:1398-409.

61. Yan YX, Shao MJ, Qi Q, Xu YS, Yang XQ, Zhu FH, He SJ, et al. Artemisinin analogue SM934 ameliorates DSS-induced mouse ulcerative colitis via suppressing neutrophils and macrophages. Acta Pharmacol Sin. 2018:39:1633-44.

62. Chen YX, Zhang XQ, Yu CG, Huang SL, Xie Y, Dou XT, Liu WJ, Zou XP. Artesunate exerts protective effects against ulcerative colitis via suppressing Toll-like receptor 4 and its downstream nuclear factor-kB signaling pathways. Mol Med Rep. 2019;20:1321-32.

63. Zhang DK, Cheng LN, Huang XL, Shi W, Xiang JY, Gan HT. Tetrandrine ameliorates dextran-sulfate-sodium-induced colitis in mice through inhibition of nuclear factor -kB activation. Int J Colorectal Dis. 2009;24:5-12.

64. Liu B, Li S, Sui X, Guo L, Liu X, Li H, Gao L, Cai S, Li Y, Wang T, Piao X. Root Extract of Polygonum cuspidatum Siebold \& Zucc. ameliorates DSSinduced ulcerative colitis by affecting NF-kappaB signaling pathway in a mouse model via synergistic effects of polydatin, resveratrol, and emodin. Front Pharmacol. 2018;9:347.

65. Tian X, Peng Z, Luo S, Zhang S, Li B, Zhou C, Fan H. Aesculin protects against DSS-Induced colitis though activating PPARY and inhibiting NF-кB pathway. Eur J Pharmacol. 2019:857:172453.

66. Xiong XJ, Li XM, He YM, Li XQ, Xu HY, Feng ML, He HB, Zhang JH, Zhu S, Komatsu K, Zou K. Effect of total triterpenoids of Chaenomeles speciosa on PPARY/SIRT1/NF-KBp65 signaling pathway and intestinal mucosal barrier of ulcerative colitis induced by DSS in mice. Zhongguo Zhong Yao Za Zhi. 2018:43:4295-304

67. Kim YJ, Ko H, Park JS, Han IH, Amor EC, Lee JW, Yang HO. Dimethyl cardamonin inhibits lipopolysaccharide-induced inflammatory factors through blocking NF-KB p65 activation. Int Immunopharmacol. 2010:10:1127-34.

68. Hatziieremia S, Gray Al, Ferro VA, Paul A, Plevin R. The effects of cardamonin on lipopolysaccharide-induced inflammatory protein production and MAP kinase and nFkappaB signalling pathways in monocytes/macrophages. Br J Pharmacol. 2006;149:188-98.

69. Ali AA, Abd Al Haleem EN, Khaleel SA, Sallam AS. Protective effect of cardamonin against acetic acid-induced ulcerative colitis in rats. Pharmacol Rep. 2017;69:268-75. 
70. Xing J, You C, Dong K, Sun J, You H, Dong Y, Sun J. Ameliorative effects of 3,4-oxo-isopropylidene-shikimic acid on experimental colitis and their mechanisms in rats. Int Immunopharmacol. 2013;15:524-31.

71. Shen P, Zhang Z, Zhu K, Cao H, Liu J, Lu X, Li Y, Jing Y, Yuan X, Fu Y, Cao $Y$, Zhang N. Evodiamine prevents dextran sulfate sodium-induced murine experimental colitis via the regulation of NF-KB and NLRP3 inflammasome. Biomed Pharmacother. 2019;110:786-95.

72. Liu X, Wang J. Anti-inflammatory effects of iridoid glycosides fraction of Folium syringae leaves on TNBS-induced colitis in rats. J Ethnopharmacol. 2011;133:780-7.

73. Fang W, Zhu S, Niu Z, Yin Y. The protective effect of syringic acid on dextran sulfate sodium-induced experimental colitis in BALB/c mice. Drug Dev Res. 2019;80:731-40.

74. Zhang Z, Liu J, Shen P, Cao Y, Lu X, Gao X, Fu Y, Liu B, Zhang N. Zanthoxylum bungeanum pericarp extract prevents dextran sulfate sodium-induced experimental colitis in mice via the regulation of TLR4 and TLR4-related signaling pathways. Int Immunopharmacol. 2016:41:127-35.

75. Sangaraju R, Nalban N, Alavala S, Rajendran V, Jerald MK, Sistla R. Protective effect of galangin against dextran sulfate sodium (DSS)induced ulcerative colitis in Balb/c mice. Inflamm Res. 2019;68:691-704.

76. Zhao ZJ, Xiang JY, Liu L, Huang XL, Gan HT. Parthenolide, an inhibitor of the nuclear factor-KB pathway, ameliorates dextran sulfate sodiuminduced colitis in mice. Int Immunopharmacol. 2012;12:169-74.

77. Kim SL, Kim SH, Park YR, Liu YC, Kim EM, Jeong HJ, Kim YN, Seo SY, Kim IH, Lee SO, Lee ST, Kim SW. Combined parthenolide and balsalazide have enhanced antitumor efficacy through blockade of NF-KB activation. Mol Cancer Res. 2017;15(2):141-51.

78. Wu X, Yang Y, Dou Y, Ye J, Bian D, Wei Z, Tong B, Kong L, Xia Y, Dai Y. Arctigenin but not arctiin acts as the major effective constituent of Arctium lappa $\mathrm{L}$. fruit for attenuating colonic inflammatory response induced by dextran sulfate sodium in mice. Int Immunopharmacol. 2014;23:505-15.

79. Yang Y, Yan H, Jing M, Zhang Z, Zhang G, Sun Y, Shan L, Yu P, Wang $Y, X U L$. Andrographolide derivative AL-1 ameliorates TNBS-induced colitis in mice: involvement of NF-KB and PPAR- $\gamma$ signaling pathways. Sci Rep. 2016;6:29716.

80. Gao Z, Yu C, Liang H, Wang X, Liu Y, Li X, Ji K, Xu H, Yang M, Liu K, Qi $D$, Fan $H$. Andrographolide derivative CX-10 ameliorates dextran sulphate sodium-induced ulcerative colitis in mice: involvement of NF-KB and MAPK signalling pathways. Int Immunopharmacol. 2018:57:82-90

81. Zhou J, Tan L, Xie J, Lai Z, Huang Y, Qu C, Luo D, Lin Z, Huang P, Su Z, Xie Y. Characterization of brusatol self-microemulsifying drug delivery system and its therapeutic effect against dextran sodium sulfateinduced ulcerative colitis in mice. Drug Deliv. 2017;24:1667-79.

82. Huang YF, Zhou JT, Qu C, Dou YX, Huang QH, Lin ZX, Xian YF, et al. Anti-inflammatory effects of Brucea javanica oil emulsion by suppressing NF-KB activation on dextran sulfate sodium-induced ulcerative colitis in mice. J Ethnopharmacol. 2017;198:389-98.

83. Chen Y, Lin Y, Li Y, Li C. Total flavonoids of Hedyotis diffusa Willd. inhibit inflammatory responses in LPS-activated macrophages via suppression of the NF-KB and MAPK signaling pathways. Exp Ther Med. 2016;11:1116-22.

84. Kim SJ, Kim YG, Kim DS, Jeon YD, Kim MC, Kim HL, Kim SY, et al. Oldenlandia diffusa ameliorates dextran sulphate sodium-induced colitis through inhibition of NF-kB activation. Am J Chin Med. 2011;39:957-69.

85. Kawai S, lijima H, Shinzaki S, Hiyama S, Yamaguchi T, Araki M, Iwatani $\mathrm{S}$, et al. Indigo Naturalis ameliorates murine dextran sodium sulfateinduced colitis via aryl hydrocarbon receptor activation. J Gastroenterol. 2017:52:904-19.

86. Xiao HT, Peng J, Hu DD, Lin CY, Du B, Tsang SW, Lin ZS, et al. Qingdai powder promotes recovery of colitis by inhibiting inflammatory responses of colonic macrophages in dextran sulfate sodium-treated mice. Chin Med. 2015;10:29.

87. Gao W, Guo Y, Wang C, Lin Y, Yu L, Sheng T, Wu Z, Gong Y. Indirubin ameliorates dextran sulfate sodium-induced ulcerative colitis in mice through the inhibition of inflammation and the induction of Foxp3expressing regulatory T cells. Acta Histochem. 2016;118:606-14.
88. Ding A, Wen X. Dandelion root extract protects NCM460 colonic cells and relieves experimental mouse colitis. J Nat Med. 2018;72:857-66.

89. Yang X, Yan Y, Li J, Tang Z, Sun J, Zhang H, Hao S, Wen A, Liu L. Protective effects of ethanol extract from Portulaca oleracea $L$. on dextran sulphate sodium-induced mice ulcerative colitis involving anti-inflammatory and antioxidant. Am J TransI Res. 2016;8:2138-48.

90. Kong R, Luo H, Wang N, Li J, Xu S, Chen K, Feng J. Portulaca extract attenuates development of dextran sulfate sodium induced colitis in mice through activation of PPARY. PPAR Res. 2018;2018:6079101.

91. Ge H, Tang H, Liang Y, Wu J, Yang Q, Zeng L, Ma Z. Rhein attenuates inflammation through inhibition of NF-KB and NALP3 inflammasome in vivo and in vitro. Drug Des Devel Ther. 2017;11:1663-71.

92. Luo S, Deng X, Liu Q, Pan Z, Zhao Z, Zhou L, Luo X. Emodin ameliorates ulcerative colitis by the flagellin-TLR5 dependent pathway in mice. Int Immunopharmacol. 2018;59:269-75.

93. Kim SJ, Kim MC, Lee BJ, Park DH, Hong SH, Um JY. Anti-inflammatory activity of chrysophanol through the suppression of NF-kappaB/ caspase-1 activation in vitro and in vivo. Molecules. 2010;15:6436-51.

94. Pandurangan AK, Mohebali N, Esa NM, Looi CY, Ismail S, Saadatdoust Z. Gallic acid suppresses inflammation in dextran sodium sulfateinduced colitis in mice: possible mechanisms. Int Immunopharmacol. 2015;28:1034-43.

95. Pandurangan AK, Ismail S, Saadatdoust Z, Esa NM. Allicin alleviates dextran sodium sulfate-(DSS-)induced ulcerative colitis in BALB/C Mice. Oxid Med Cell Longev. 2015;2015:605208.

96. Kim SJ, Kim KW, Kim DS, Kim MC, Jeon YD, Kim SG, Jung HJ, et al. The protective effect of Cassia obtusifolia on DSS-induced colitis. Am J Chin Med. 2011;39:565-77.

97. Wang K, Li YF, LV Q, Li XM, Dai Y, Wei ZF. Bergenin, acting as an agonist of PPARY, ameliorates experimental colitis in mice through improving expression of SIRT1, and therefore inhibiting NF-KB-mediated macrophage activation. Front Pharmacol. 2018;8:981.

98. Ge F, Zhu S, Liu L, Yan J, Ji Y, Sun Z. Anti-inflammatory effects of Fagopyrum cymosum administered as a potential drug for ulcerative colitis. Exp Ther Med. 2017;14:4745-54.

99. Gao W, Wang C, Yu L, Sheng T, Wu Z, Wang X, Zhang D, Lin Y, Gong Y. Chlorogenic acid attenuates dextran sodium sulfate-induced ulcerative colitis in mice through MAPKJERK/JNK pathway. Biomed Res Int. 2019;2019:6769789.

100. Ishiguro K, Ando T, Maeda O, Hasegawa M, Kadomatsu K, Ohmiya N, Niwa Y, Xavier R, Goto H. Paeonol attenuates TNBS-induced colitis by inhibiting NF-kappaB and STAT1 transactivation. Toxicol Appl Pharmacol. 2006;217:35-42.

101. Zhang Z, Yang L, Wang B, Zhang L, Zhang Q, Li D, Zhang S, Gao H, Wang $X$. Protective role of liriodendrin in mice with dextran sulphate sodiuminduced ulcerative colitis. Int Immunopharmacol. 2017;52:203-10.

102. Andújar I, Ríos JL, Giner RM, Miguel Cerdá J, Recio Mdel C. Beneficial effect of shikonin on experimental colitis induced by dextran sulfate sodium in BALB/c mice. Evid Based Complement Alternat Med. 2012;2012:271606.

103. He X, Zheng Z, Yang X, Lu Y, Chen N, Chen W. Tetramethylpyrazine attenuates PPAR- $\gamma$ antagonist-deteriorated oxazolone-induced colitis in mice. Mol Med Rep. 2012;5:645-50.

104. Kazi HA, Qian Z. Crocetin reduces TNBS-induced experimental colitis in mice by downregulation of NFkB. Saudi I Gastroenterol. 2009;15:181-7.

105. Zhang H, Deng A, Zhang Z, Yu Z, Liu Y, Peng S, Wu L, Qin H, Wang W. The protective effect of epicatechin on experimental ulcerative colitis in mice is mediated by increasing antioxidation and by the inhibition of NF-KB pathway. Pharmacol Rep. 2016;68:514-20.

106. Dryden GW, Lam A, Beatty K, Qazzaz HH, McClain CJ. A pilot study to evaluate the safety and efficacy of an oral dose of (-)-epigallocatechin3-gallate-rich polyphenon $\mathrm{E}$ in patients with mild to moderate ulcerative colitis. Inflamm Bowel Dis. 2013;19(9):1904-12.

107. Salomon N, Lang A, Gamus D. Curcumin add-on therapy for ulcerative colitis. Harefuah. 2015;154(56-8):66.

108. Vecchi Brumatti L, Marcuzzi A, Tricarico PM, Zanin V, Girardelli M, Bianco AM. Curcumin and inflammatory bowel disease: potential and limits of innovative treatments. Molecules. 2014;19:21127-53.

109. Sreedhar R, Arumugam S, Thandavarayan RA, Karuppagounder V, Watanabe K. Curcumin as a therapeutic agent in the chemoprevention of inflammatory bowel disease. Drug Discov Today. 2016;21:843-9. 
110. Wang $Y$, Tang $Q$, Duan P, Yang L. Curcumin as a therapeutic agent for blocking NF-kB activation in ulcerative colitis. Immunopharmacol Immunotoxicol. 2018;40(6):476-82.

111. Arafa HM, Hemeida RA, El-Bahrawy Al, Hamada FM. Prophylactic role of curcumin in dextran sulfate sodium (DSS)-induced ulcerative colitis murine model. Food Chem Toxicol. 2009:47:1311-7.

112. Li CP, Li JH, He SY, Chen O, Shi L. Effect of curcumin on P38MAPK expression in DSS-induced murine ulcerative colitis. Genet Mol Res. 2015:14:3450-8

113. Lv Q, Qiao SM, Xia Y, Shi C, Xia YF, Chou GX, Wang ZT, Dai Y, Wei ZF. Norisoboldine ameliorates DSS-induced ulcerative colitis in mice through induction of regulatory T cells in colons. Int Immunopharmacol. 2015;29:787-97.

114. He W, Li Y, Liu M, Yu H, Chen Q, Chen Y, Ruan J, Ding Z, Zhang Y, Wang T. Citrus aurantium L. and its flavonoids regulate TNBS-induced inflammatory bowel disease through anti-inflammation and suppressing isolated jejunum contraction. Int J Mol Sci. 2018;19:3057.

115. Kim DS, Kim SH, Kee JY, Han YH, Park J, Mun JG, Joo MJ, et al. Eclipta prostrata improves DSS-induced colitis through regulation of inflammatory response in intestinal epithelial cells. Am J Chin Med. 2017:45:1047-60.

116. LV J, Zhang Y, Tian Z, Liu F, Shi Y, Liu Y, Xia P. Astragalus polysaccharides protect against dextran sulfate sodium-induced colitis by inhibiting NF-kB activation. Int J Biol Macromol. 2017;98:723-9.

117. Wu S, Chen Z. Astragaloside IV alleviates the symptoms of experimental ulcerative colitis in vitro and in vivo. Exp Ther Med. 2019;18:2877-84

118. Liu D, Huo X, Gao L, Zhang J, Ni H, Cao L. NF-kB and Nrf2 pathways contribute to the protective effect of Licochalcone A on dextran sulphate sodium-induced ulcerative colitis in mice. Biomed Pharmacother. 2018;102:922-9.

119. Yuan $H$, Ji WS, Wu KX, Jiao JX, Sun LH, Feng YT. Anti-inflammatory effect of diammonium glycyrrhizinate in a rat model of ulcerative colitis. World J Gastroenterol. 2006;12:4578-81.

120. Kim SJ, Kim MC, Um JY, Hong SH. The beneficial effect of vanillic acid on ulcerative colitis. Molecules. 2010;15:7208-17.

121. Gu P, Zhu L, Liu Y, Zhang L, Liu J, Shen H. Protective effects of paeoniflorin on TNBS-induced ulcerative colitis through inhibiting NF-kappaB pathway and apoptosis in mice. Int Immunopharmacol. 2017:50:152-60

122. Periasamy S, Wu WH, Chien SP, Liu CT, Liu MY. Dietary Ziziphus jujuba fruit attenuates colitis-associated tumorigenesis: a pivotal role of the NF-KB/L-6/JAK1/STAT3 pathway. Nutr Cancer. 2019:72:1-13.

123. Kim KJ, Park JM, Lee JS, Kim YS, Kangwan N, Han YM, et al. Oligonol prevented the relapse of dextran sulfate sodium-ulcerative colitis through enhancing NRF2-mediated antioxidative defense mechanism. J Physiol Pharmacol. 2018. https://doi.org/10.26402/jpp.2018.3.03.

124. Shi L, Lin Q, Yang T, Nie Y, Li X, Liu B, Shen J, Liang Y, Tang Y, Luo F. Oral administration of Lentinus edodes $\beta$-glucans ameliorates DSS-induced ulcerative colitis in mice via MAPK-Elk-1 and MAPK-PPARy pathways. Food Funct. 2016;7:4614-27.

125. Kim H, Banerjee N, Barnes RC, Pfent CM, Talcott ST, Dashwood RH, Mertens-Talcott SU. Mango polyphenolics reduce inflammation in intestinal colitis-involvement of the miR-126/PI3K/AKT/mTOR axis in vitro and in vivo. Mol Carcinog. 2017;56:197-207.

126. Cai SS, Zhu YQ, Zhu XW, Zhang H, Mei JJ. Therapeutic effects of muscovite on ulcerative colitis in rats. Zhonghua Yi Xue Za Zhi. 2013;93:2220-4

127. Kang DG, Moon MK, Lee AS, Kwon TO, Kim JS, Lee HS. Cornuside suppresses cytokine-induced proinflammatory and adhesion molecules in the human umbilical vein endothelial cells. Biol Pharm Bull. 2007;30(9):1796-9.

128. Chu Q, Hashimoto K, Satoh K, Wang Q, Sakagami H. Effect of three herbal extracts on NO and PGE2 production by activated mouse macrophage-like cells. Vivo. 2009;23:537-44.

129. Jang SE, Jeong JJ, Hyam SR, Han MJ, Kim DH. Ursolic acid isolated from the seed of Cornus officinalis ameliorates colitis in mice by inhibiting the binding of lipopolysaccharide to Toll-like receptor 4 on macrophages. J Agric Food Chem. 2014;62:9711-21.

130. Shin JS, Cho EJ, Choi HE, Seo JH, An HJ, Park HJ, Cho YW, Lee KT. Antiinflammatory effect of a standardized triterpenoid-rich fraction isolated from Rubus coreanus on dextran sodium sulfate-induced acute colitis in mice and LPS-induced macrophages. J Ethnopharmacol. 2014;158 Pt $A(1): 291-300$.

131. Lee JE, Cho SM, Park E, Lee SM, Kim Y, Auh JH, Choi HK, Lim S, Lee SC, Kim JH. Anti-inflammatory effects of Rubus coreanus Miquel through inhibition of NF-KB and MAP Kinase. Nutr Res Pract. 2014;8:501-8.

132. Fan H, Gao Z, Ji K, Li X, Wu J, Liu Y, Wang X, Liang H, Liu Y, Li X, Liu P, Chen $D$, Zhao $F$. The in vitro and in vivo anti-inflammatory effect of osthole, the major natural coumarin from Cnidium monnieri (L.) Cuss, via the blocking of the activation of the NF-KB and MAPK/p38 pathways. Phytomedicine. 2019;58:152864.

133. Lv WJ, Liu C, Li YF, Chen WQ, Li ZQ, LiY, Xiong Y, Chao LM, Xu XL, Guo SN. Systems pharmacology and microbiome dissection of Shen Ling Bai Zhu San reveal multiscale treatment strategy for IBD. Oxid Med Cell Longev. 2019;2019:8194804.

134. Hu Z, Yang M, Ye Q, Qin K, Wu M, Gu R, Zhou Y. Tou Nong San attenuates inflammation in TNBS-IBD model by inhibiting NF-KB signaling pathway. Evid Based Complement Alternat Med. 2018;2018:6929307.

135. Lin X, Yi Z, Diao J, Shao M, Zhao L, Cai H, Fan Q, Yao X, Sun X. Shao Yao decoction ameliorates colitis-associated colorectal cancer by downregulating proinflammatory cytokines and promoting epithelialmesenchymal transition. J TransI Med. 2014;12:105.

136. Zhu L, Dai LM, Shen H, Gu PQ, Zheng K, Liu YJ, Zhang L, Cheng JF. Qing Chang Hua Shi granule ameliorate inflammation in experimental rats and cell model of ulcerative colitis through MEK/ERK signaling pathway. Biomed Pharmacother. 2019;116:108967.

137. Shen H, Liu ZQ, Zhu Q, Zhu L, Zhai JH. Effect of qingchang huash recipe on NF-kappaB/Tolls pathway in ulcerative colitis patients and mechanism study. Zhongguo Zhong Xi Yi Jie He Za Zhi. 2013;33:1216-20.

138. Xu BL, Zhang GJ, Ji YB. Active components alignment of Gegenqinlian decoction protects ulcerative colitis by attenuating inflammatory and oxidative stress. J Ethnopharmacol. 2015;162:253-60.

139. Li R, Chen Y, Shi M, Xu X, Zhao Y, Wu X, Zhang Y. Gegen Qinlian decoction alleviates experimental colitis via suppressing TLR4/ NF-KB signaling and enhancing antioxidant effect. Phytomedicine. 2016;23:1012-20.

140. Zheng L, Zhang YL, Dai YC, Chen X, Chen DL, Dai YT, Tang ZP. Jianpi Qingchang decoction alleviates ulcerative colitis by inhibiting nuclear factor-KB activation. World J Gastroenterol. 2017;23:1180-8.

141. Chen YL, Zheng YY, Dai YC, Zhang YL, Tang ZP. Systems pharmacology approach reveals protective mechanisms of Jian-Pi Qing-Chang decoction on ulcerative colitis. World J Gastroenterol. 2019;25:2603-22.

142. Wang X, Fan F, Cao Q. Modified pulsatilla decoction attenuates oxazolone-induced colitis in mice through suppression of inflammation and epithelial barrier disruption. Mol Med Rep. 2016;14:1173-9.

143. Ke X, Zhou F, Gao Y, Xie B, Hu G, Fang W, Peng J, Chen Y, Sferra TJ. Qing Hua Chang Yin exerts therapeutic effects against ulcerative colitis through the inhibition of the TLR4/NF-KB pathway. Int J Mol Med. 2013;32:926-30.

144. Ke X, Hu G, Fang W, Chen J, Zhang X, Yang C, Peng J, Chen Y, Sferra TJ. Qing Hua Chang Yin inhibits the LPS-induced activation of the IL-6/ STAT3 signaling pathway in human intestinal Caco-2 cells. Int J Mol Med. 2015:35:1133-7.

145. Lin JC, Wu JQ, Wang F, Tang FY, Sun J, Xu B, Jiang M, et al. QingBai decoction regulates intestinal permeability of dextran sulphate sodium-induced colitis through the modulation of notch and NF-KB signalling. Cell Prolif. 2019;52:e12547.

146. Mi H, Liu FB, Li HW, Hou JT, Li PW. Anti-inflammatory effect of Chang-An-Shuan on TNBS-induced experimental colitis in rats. BMC Complement Altern Med. 2017;17:315.

147. Xu X, Zhang L, Liu Z, Pan Y, Chen D, Yang Z, Deng Q, Cao X, Sun YU, Yang $Z$, Hoffman RM, Yuan H. Therapeutic efficacy of the traditional Chinese Medicine Baishaogiwu on TNBS-induced colitis is associated with down-regulation of the TLR4/MyD88/NF-KB signaling pathway. Vivo. 2016;30:181-6.

148. Han XH, Zhong J, Guo JY, Shi R, Wang XH, Wang CH, Wang K, Du GL, Shen YH, Ma YM. Relationships between pharmacokinetics and efficacy of Xie-xin decoction in rats with experimental ulcerative colitis. J Ethnopharmacol. 2013;148:182-9.

149. Xu M, Duan XY, Chen QY, Fan H, Hong ZC, Deng SJ, Nan Z, Wu H, Dong YL, Liu YJ, Zhou CZ. Effect of compound sophorae decoction 
on dextran sodium sulfate (DSS)-induced colitis in mice by regulating Th17/Treg cell balance. Biomed Pharmacother. 2019;109:2396-408.

150. He Z, Zhou Q, Wen K, Wu B, Sun X, Wang X, Chen Y. Huangkui Lianchang decoction ameliorates DSS-induced ulcerative colitis in mice by inhibiting the NF-kappaB signaling pathway. Evid Based Complement Alternat Med. 2019;2019:1040847.

151. Yan P, Qin O. Therapeutic effect and mechanisms study of Bawei Xilei Powder on ulcerative colitis patients. Zhongguo Zhong Xi Yi Jie He Za Zhi. 2014;34:27-30.

152. Chen G, Yang Y, Liu M, Teng Z, Ye J, Xu Y, Cai X, Cheng X, Yang J, Hu C, Wang M, Cao P. Banxia xiexin decoction protects against dextran sulfate sodium-induced chronic ulcerative colitis in mice. J Ethnopharmacol. 2015;166:149-56.

153. Fan H, Shen L, Tang Q, Xiong P, Shou Z, Liao Y, Liang L, Chen X. Effect of Wumeiwan on cytokines TNF-alpha, IL-6, IL-8, IL-10 and expression of NF-kappaBp65 in rats with ulcerative colitis. J Huazhong Univ Sci Technolog Med Sci. 2009;29:650-4.

154. Tsang SW, Ip SP, Wu JC, Ng SC, Yung KK, Bian ZX. A Chinese medicinal formulation ameliorates dextran sulfate sodium-induced experimental colitis by suppressing the activity of nuclear factor-kappaB signaling. J Ethnopharmacol. 2015;162:20-30.

155. Zhang Z, Shen P, Xie W, Cao H, Liu J, Cao Y, Zhang N. Pingwei San ameliorates dextran sulfate sodium-induced chronic colitis in mice. J Ethnopharmacol. 2019;236:91-9.

156. Wang H, Li SH, Zhang Y, Guan J, Wu YM, Wang Q, Luo XQ. Therapeutic efficacy and mechanism of Zhenrenyangzang decoction in rats with experimental ulcerative colitis. Int J Clin Exp Med. 2015;8:15254-61.

157. Tang M, Lu Q, Liu H, He M, Guo Q, Zhao Y, Zhang C. Research progress of ulcerative colitis related signaling pathways. Chin Pharmacol Bull. 2018;12:1642-7

158. Atreya I, Atreya R, Neurath MF. NF-kappaB in inflammatory bowel disease. J Intern Med. 2008;263(6):591-6.

159. Neurath MF, Pettersson S, Meyer zum Buschenfelde KH, Strober W. Local administration of antisense phosphorothioate oligonucleotides to the p65 subunit of NF-kappa B abrogates established experimental colitis in mice. Nat Med. 1996;2:998-1004.

160. Gelbmann CM, Leeb SN, Vogl D, Maendel M, Herfarth H, Scholmerich J, Falk W, Rogler G. Inducible CD40 expression mediates NFkappaB activation and cytokine secretion in human colonic fibroblasts. Gut. 2003:52:1448-56

161. Wang L, Walia B, Evans J, Gewirtz AT, Merlin D, Sitaraman SV. IL-6 induces NF-kappa B activation in the intestinal epithelia. J Immunol. 2003;171:3194-201.
162. Zhou Y, Tao H, Wang A, Zhong Z, Wu X, Wang M, Bian Z, Wang S, Wang Y. Chinese herb pair Paeoniae Radix Alba and Atractylodis Macrocephalae Rhizoma suppresses LPS-induced inflammatory response through inhibiting MAPK and NF-KB pathway. Chin Med. 2019;14:2.

163. Sang W, Zhong Z, Linghu K, Xiong W, Tse AKW, Cheang WS, Yu H, Wang Y. Siegesbeckia pubescens Makino inhibits Pam3CSK4-induced inflammation in RAW 264.7 macrophages through suppressing TLR1/ TLR2-mediated NF-KB activation. Chin Med. 2018;13:37.

164. Dong Y, Feng ZL, Chen HB, Wang FS, Lu JH. Corni Fructus: a review of chemical constituents and pharmacological activities. Chin Med. 2018;13:34.

165. Wang A, Keita ÅV, Phan V, McKay CM, Schoultz I, Lee J, Murphy MP, et al. Targeting mitochondria-derived reactive oxygen species to reduce epithelial barrier dysfunction and colitis. Am J Pathol. 2014;184:2516-27.

166. Khor TO, Huang MT, Kwon KH, Chan JY, Reddy BS, Kong AN. Nrf2deficient mice have an increased susceptibility to dextran sulfate sodium-induced colitis. Cancer Res. 2006:66:11580-4.

167. Cuadrado A, Manda G, Hassan A, Alcaraz MJ, Barbas C, Daiber A, Ghezzi P, et al. Transcription factor NRF2 as a therapeutic target for chronic diseases: a systems medicine approach. Pharmacol Rev. 2018;70:348-83

168. Zhao L, Zhang S, He P. Mechanistic understanding of herbal therapy in inflammatory bowel disease. Curr Pharm Des. 2017;23(34):5173-9.

169. Sałaga M, Zatorski H, Sobczak M, Chen C, Fichna J. Chinese herbal medicines in the treatment of IBD and colorectal cancer: a review. Curr Treat Opt Oncol. 2014;15(3):405-20.

170. Clapper ML, Cooper HS, Chang WC. Dextran sulfate sodium-induced colitis-associated neoplasia: a promising model for the development of chemopreventive interventions. Acta Pharmacol Sin. 2007;28(9):1450-9.

171. Sha T, Igaki K, Yamasaki M, Watanabe T, Tsuchimori N. Establishment and validation of a new semi-chronic dextran sulfate sodium-induced model of colitis in mice. Int Immunopharmacol. 2013;15(1):23-9.

172. Gao C, Liu L, Zhou Y, Bian Z, Wang S, Wang Y. Novel drug delivery systems of Chinese medicine for the treatment of inflammatory bowel disease. Chin Med. 2019:14:23.

\section{Publisher's Note}

Springer Nature remains neutral with regard to jurisdictional claims in published maps and institutional affiliations.
Ready to submit your research? Choose BMC and benefit from:

- fast, convenient online submission

- thorough peer review by experienced researchers in your field

- rapid publication on acceptance

- support for research data, including large and complex data types

- gold Open Access which fosters wider collaboration and increased citations

- maximum visibility for your research: over 100M website views per year

At BMC, research is always in progress.

Learn more biomedcentral.com/submissions 